\title{
On bromine, nitrogen oxides and ozone depletion in the tropospheric plume of Erebus volcano (Antarctica)
}

\author{
Marie Boichu ${ }^{\mathrm{a},}$, Clive Oppenheimer ${ }^{\mathrm{a}} \underline{\text { b }}, \underline{\mathrm{c}}$, Tjarda J. Roberts ${ }^{\underline{\mathrm{d}}}$, Vitchko Tsanev ${ }^{\mathrm{e}}$, Philip \\ R. Kyle ${ }^{\mathbf{f}}$
}

a University of Cambridge, Department of Geography, Downing Place, Cambridge CB2 3EN, United Kingdom

${ }^{\mathrm{b}}$ Le Studium, Institute for Advanced Studies, Orléans and Tours, France

c Institut des Sciences de la Terre d'Orléans, Université d'Orléans, 1a rue de la Férollerie, 45071 Orléans, France

${ }^{\mathrm{d}}$ Norwegian Polar Institute, FRAM Centre, 9296 Troms $\varnothing$, Norway

e University of Cambridge, Department of Chemistry, Lensfield Road, Cambridge CB2 1EW, United Kingdom

$\mathrm{f}$ New Mexico Institute of Mining and Technology, Department of Earth and Environmental Science, Socorro, NM 87801, USA

\begin{abstract}
Since the discovery of bromine oxide $(\mathrm{BrO})$ in volcanic emissions, there has been speculation concerning its role in chemical evolution and notably ozone depletion in volcanic plumes. We report the first measurements using Differential Optical Absorption Spectroscopy (DOAS) of $\mathrm{BrO}$ in the tropospheric plume of the persistently degassing Erebus volcano (Antarctica). These are the first observations pertaining to emissions from an alkaline phonolitic magma. The observed $\mathrm{BrO} / \mathrm{SO}_{2}$ ratio of $2.5 \times 10^{-4}$ is similar to that measured at andesitic arc volcanoes. The high abundance of $\mathrm{BrO}$ is consistent with high abundances of $\mathrm{F}$ and $\mathrm{Cl}$ relative to sulfur in the Erebus plume.
\end{abstract}

Our estimations of $\mathrm{HBr}$ flux and $\mathrm{BrO}$ production rate suggest that reactive bromine chemistry can explain a $35 \%$ loss of tropospheric $\mathrm{O}_{3}$ observed in the Erebus plume at approximately $30 \mathrm{~km}$ from source (Oppenheimer et al., 2010).

Erebus also has a permanent lava lake, which could result in generation of $\mathrm{NO}_{x}$ by thermal fixation of atmospheric $\mathrm{N}_{2}$ at the hot lava surface. Any $\mathrm{NO}_{x}$ emission could play a potent role in reactive bromine chemistry. However, the presence of $\mathrm{NO}_{2}$ could not be detected in the plume, about $400 \mathrm{~m}$ above the lake, in our DOAS observations of 2005. Nor could we reproduce spectroscopic retrievals that reportedly identified $\mathrm{NO}_{2}$ in DOAS observations from 2003 made of the Erebus plume (Oppenheimer et al., 2005). Based on the $\mathrm{NO}_{2}$ detection limit of our analysis, we can state an upper limit of the $\mathrm{NO}_{2} / \mathrm{SO}_{2}$ ratio of $\leq 0.012$, an order of magnitude lower than previously reported. Our new result supports a rapid oxidation of $\mathrm{NO}_{x}$ in the young plume and is more consistent with measurements of $\mathrm{NO}_{y}$ species measured using an instrumented aircraft flying in the plume. Model simulations, tuned for Erebus, were performed to reproduce the $\mathrm{BrO} / \mathrm{SO}_{2}$ observed in the young plume and to investigate the impact of $\mathrm{NO}_{x}$ emissions at source on the subsequent formation of $\mathrm{BrO}$ in the plume. They support our hypothesis of rapid conversion of $\mathrm{NO}_{x}$ to $\mathrm{NO}_{y}$ in the vicinity of the lava lake. This study thus places new constraints on the interaction between reactive nitrogen and bromine species in volcanic plumes, and its effects on ozone. 


\section{Highlights}

1st observation of $\mathrm{BrO}$ simultaneously to $\mathrm{O}_{3}$ depletion in a volcanic plume. 1 st detection of $\mathrm{BrO}$ in the plume of Erebus which impacts the Antarctic troposphere. 1 st detection of $\mathrm{BrO}$ for a phonolitic volcano. Reactive Br chemistry can cause the ozone depletion observed in the plume of Erebus. Observations and model simulations support a rapid conversion of $\mathrm{NO}_{x}$ to $\mathrm{NO}_{y}$ species.

Keywords: Volcanic plume; Antarctic troposphere; Reactive bromine chemistry; Reactive nitrogen chemistry; Ozone depletion; Phonolitic magma

\section{Introduction}

Both the sustained 'quiescent' degassing of volcanoes (Halmer et al., 2002) and sporadic explosive eruptions contribute significant quantities of reactive gases and aerosols to the atmosphere ( [Robock and Oppenheimer, 2003] , [Oppenheimer et al., 2003] , [Mather, 2008] and [von Glasow et al., 2009] ). Much attention has been paid to major gases including $\mathrm{CO}_{2}$, an important greenhouse gas, $\mathrm{SO}_{2}$ a precursor for sulfate aerosols which impact radiative forcing, and $\mathrm{HCl}$ and $\mathrm{HF}$ responsible for acid deposition with potentially significant environmental and agronomic impacts. The reactive trace halogen species, $\mathrm{BrO}$, was first reported in volcanic plumes by Bobrowski et al. (2003) (see Table 1 for a review of all available observations to date). Also, reactive trace nitrogen species have been identified ( [Hobbs et al., 1982] , [Hobbs et al., 1991] , [Huebert et al., 1999] , [Mather et al., 2004b] and [Oppenheimer et al., 2005] ). Reactive nitrogen oxides $\left(\mathrm{NO}_{x}\right)$ are thought to be generated initially via thermal fixation of atmospheric $\mathrm{N}_{2}$ near the surface of a hot lava body and/or in a high-temperature mixture of magmatic and atmospheric gases, followed by in-plume oxidation ( [Huebert et al., 1999] , [Mather et al., 2004b] , [Oppenheimer et al., 2005] and [Martin et al., 2006] ). Reactive halogens are not emitted directly from magma, but are formed from hydrogen halides (e.g., $\mathrm{HCl}$ and $\mathrm{HBr}$ ) (Gerlach, 2004) as a result of heterogeneous chemical reactions during plume transport and mixing with background air ( [Oppenheimer et al., 2006] and [Bobrowski et al., 2007] ). The autocatalytic formation of $\mathrm{BrO}$ (also called the 'BrO explosion') is the result of a complex sequence of reactions taking place in the plume. It first involves gas phase reactions generating $\mathrm{HOBr}$ and $\mathrm{BrONO}_{2}$ and/or $\mathrm{BrNO}_{2}$ which then heterogeneously interact with acid aerosols to form $\mathrm{Br}_{2}$ or $\mathrm{BrCl}$ species. Further photolysis and reaction with $\mathrm{O}_{3}$ sourced by entrainment of ambient air, generates $\mathrm{BrO}$. Readers are referred to the review of von Glasow and Crutzen (2003) and papers of [Oppenheimer et al., 2006] , [Bobrowski et al., 2007] and [Roberts et al., 2009] and von Glasow (2010) for a more complete and detailed description of these sequences of chemical reactions. Despite their low abundances, reactive halogens can play a key role in a volcanic plume as they have the potential to consume ambient $\mathrm{O}_{3}$ ( [Bobrowski et al., 2003] and [Roberts et al., 2009] ), which is fundamental in the troposphere, as the primary source of hydroxyl radicals and as a strong oxidizing agent. $\mathrm{NO}_{x}$ species also deserve attention since they can strongly perturb reactive halogen chemistry. Whereas observations of ozone depletion have been made in volcanic plumes from Mt. St. Helens (Hobbs et al., 1982), Hekla (Rose et al., 2006) and Eyjafjallajökull (Schumann et al., 2010), the simultaneous presence of reactive halogens in a tropospheric plume has not been reported previously. 
Erebus volcano provides an exceptional opportunity to understand the chemical evolution of volcanic plumes and their impact on the troposphere. Because of its southerly location on Ross Island in Antarctica $\left(77^{\circ} 32^{\prime} \mathrm{S}, 167^{\circ} 10^{\prime} \mathrm{E}\right)$, this volcano affects the near pristine polar atmosphere (Graf et al., 2010). It also presents a sustained activity, as it degasses persistently from a permanent lava lake, first observed in the 1970s ( [Giggenbach et al., 1973] and [Kyle et al., 1982] ), but possibly already present in 1841 (Ross, 1847). The summit crater of the volcano reaches up to $3794 \mathrm{~m}$ in altitude typically entraining the plume at a height of close to $4000 \mathrm{~m}$ above sea level. This promotes a long atmospheric lifetime of gas and aerosol species and a consequently wide dispersion (Graf et al., 2010). The influence of Erebus' degassing has been identified more than $1000 \mathrm{~km}$ away above the polar plateau thanks to numerous observations: particle, trace metals and chlorine deposits ( [Chuan et al., 1986] , [Chuan, 1994] , [Zoller et al., 1974] , [Meeker et al., 1991] and [Zreda-Gostynska et al., 1997] ), as well as airborne sulfate aerosols, $\mathrm{SO}_{2}$ and gas phase $\mathrm{NO}_{y}$ species (Slusher et al., 2010). Ice cores from East Antarctica contain also evidence of volcanic (Erebus) input (Vallelonga et al., 2002). Determining the exact influence of Erebus' emissions, including reactive trace species, is thus important for understanding the state of the Antartic troposphere and even for interpretation of glaciochemical records extracted from the polar ice.

The data already gathered at this volcano are extensive. They include near-source rim observations of gas flux and composition ( [Zreda-Gostynska et al., 1993] , [Zreda-Gostynska et al., 1997] , [Kyle et al., 1994] , [Wardell et al., 2004] , [Sweeney et al., 2008] , [Oppenheimer and Kyle, 2008] and [Boichu et al., 2010] ), and of particle emissions ( [Meeker et al., 1991] , [Zreda-Gostynska et al., 1997] , [Wardell et al., 2008] and [Ilyinskaya et al., 2010] ), but also airborne in-situ measurements of aerosols ( [Radke, 1982] , [Chuan et al., 1986] , [Chuan, 1994] and [Oppenheimer et al., 2010] ) and various gas species in the aged plume ( [Rose et al., 1985] and [Oppenheimer et al., 2010] ). Oppenheimer et al. (2010) recently showed evidence for ozone depletion in the plume, $\sim 30 \mathrm{~km}$ downwind from source. This result importantly demonstrates ozone depletion in plumes within the free troposphere, in contrast to boundary-layer ozone depletion events (ODE's) that occur during springtime in Antarctica as solar radiation becomes available (see Simpson et al., 2007, for a review). As a consequence, the impact of in-plume reactive bromine chemistry on this destruction of $\mathrm{O}_{3}$ begs investigation.

Here we report the first differential optical absorption spectroscopy (DOAS) observations of $\mathrm{BrO}$ in the Erebus plume in December 2005. These are the first observations pertaining to phonolitic magma (see Table 1). Together with calculations of $\mathrm{HBr}$ source emissions, this enables evaluation of the dynamics of the 'BrO explosion' at this volcano.

Oppenheimer et al. (2005) reported the presence of $\mathrm{NO}_{2}$ in the Erebus plume based on evaluation of ultraviolet spectra collected in December 2003. However, $\mathrm{NO}_{2}$ was not detected in DOAS measurements and observations from instrumented aircraft flying in the plume (Oppenheimer et al., 2010) collected in December 2005. To investigate this puzzling observation, we also carry out here a reassessment of the DOAS observations reported by Oppenheimer et al. (2005) and find a weaker abundance of $\mathrm{NO}_{2}$ than previously reported. Our observations and model simulations of reactive plume chemistry clarify aspects of the conversion of $\mathrm{NO}_{x}$, produced at the lava lake, to $\mathrm{NO}_{y}$ species, and the impact on reactive $\mathrm{Br}$ chemistry. In the light of our new estimations of $\mathrm{BrO}, \mathrm{HBr}$ and $\mathrm{NO}_{x}$ abundances, and application of recently developed models of the chemical evolution of volcanic plumes, we offer a qualitative evaluation of the impact of Erebus on polar tropospheric ozone. 


\section{Methodology}

\subsection{Experiment description}

UV DOAS measurements were collected in December 2005, from Lower Erebus Hut at $\sim 2 \mathrm{~km}$ from the crater rim. Spectra were collected with two thermo-stabilized $\left(\sim 15^{\circ} \mathrm{C}\right)$ Ocean Optics USB2000 spectrometers spanning a wavelength range of about $288-434 \mathrm{~nm}$ with a resolution of $\sim 0.45 \mathrm{~nm}$ and $0.60 \mathrm{~nm}$ (FWHM). The spectrometers were coupled to a simple quartz-lens telescope (field of view of $8 \mathrm{mrad}$ ) held in a fixed position above the crater (elevation of $15^{\circ}$ ). A young plume of $\sim 3-7$ min after emission from the lava lake was sampled, assuming a typical rise rate for the plume of $1-2.5 \mathrm{~m} \mathrm{~s}^{-1}$ (Boichu et al., 2010) and a lava lake at $3515 \mathrm{~m}$ above sea level (Csatho et al., 2008). Spectra were recorded with a total integration time ranging between 5 and $10 \mathrm{~s}$ (details are given in Table 2 and Table 3). DOAS observations on 11 December 2003, reported by Oppenheimer et al. (2005), were reexamined. These spectra were collected from the same location under similar conditions (total integration time of $8 \mathrm{~s}$ ), except the telescope was mounted on a platform rotating so as to scan the vertically rising plume. The spectrometer, with an elevation of $14^{\circ}$, was viewing a $\sim 2.5-$ 6 min old plume.

\subsection{Spectroscopic retrieval}

$\mathrm{SO}_{2}, \mathrm{BrO}$ and $\mathrm{NO}_{2}$ column amounts were retrieved following DOAS procedures (Platt and Stutz, 2008). For December 2005 data, a moving average of 5 consecutive spectra was used to increase the signal-to-noise ratio before the DOAS analysis. The reference spectra included in the non-linear fit were obtained by convolving high-resolution absorption cross-sections of $\mathrm{SO}_{2}$ (243 K, air) (Bogumil et al., 2003), BrO (243 K, air) (Fleischmann et al., 2004), $\mathrm{O}_{3}$ (223 K, air) (Voigt et al., 2001) and $\mathrm{O}_{4}(296 \mathrm{~K}, 335-666 \mathrm{~nm}$, from Hermans, 2002), with the instrumental line shape. For testing the presence of nitrogen species in the plume, $\mathrm{NO}_{2}$ (246 K, air) (Voigt et al., 2002) and HONO (298 K, air) (Stutz et al., 2000) high-resolution absorption cross-sections were also used. The temperatures chosen for these laboratory crosssections correspond to tropospheric and stratospheric temperatures at Erebus (except for $\mathrm{O}_{4}$ and HONO cross-sections only available for 296-298 K). Temperatures at Erebus summit in December were typically around 243-253 K. Stratospheric temperatures at $20 \mathrm{~km}$ altitude averaged over 50 years during the months of December to February, are approximately 230 $240 \mathrm{~K}$, with a maximum variation of $-15 \mathrm{~K}$ about the mean (David et al., 2010).

DOAS analysis is usually performed in the optical density space. However, small differences in the calibration of collected and background spectra (e.g. due to thermal effects) may generate high-frequency artifacts in the optical density, resulting in an increase of the noise level. To tackle this issue, the DOAS analysis was made in the intensity space and the logarithm of the background spectrum was included as a cross-section in the fitting routine. The coefficient of this 'artificial' cross-section must be very close to 1 to validate the method, and this was verified afterward. A Ring spectrum (Fish and Jones, 1995), calculated from the background spectrum using DOASIS software (Kraus, 2006), was also included in the fit, as well as a third order polynomial to remove broad band structures from the logarithm of the measured intensity spectra. In the non-linear fit, shift and squeeze permitted for the reference spectra were constrained by the values of shift and squeeze evaluated for the logarithm of the background spectrum, which ranged in $0.97-1.03$ and $[-0.3 ; 0.3] \mathrm{nm}$, respectively. 
The instrumental line shape was determined using WinDOAS (IASB/BIRA software developed by C. Fayt and M. Van Roozendael) by fitting a measured Fraunhofer spectrum to the Kurucz high-resolution spectrum convolved with the instrument line shape chosen to be a wavelength dependent gaussian function (taking the Ring effect and the absorption of $\mathrm{O}_{3}$ into account). Background spectra were identified from the collected spectra as those with the lowest retrieved $\mathrm{SO}_{2}$ column amount for each group of data. A fitting window covering both $\mathrm{SO}_{2}$ and $\mathrm{BrO}$ absorption ranges (310.9-377.8 $\mathrm{nm}$ ) was selected to yield a fit residual with minimal standard deviation, but also to include a sufficient number of absorption bands to constrain well the fit of both absorbers $\left(\sim 10\right.$ bands for $\mathrm{BrO}$ and 4 for $\left.\mathrm{SO}_{2}\right)$. The fit residual still contained some structure associated to $\mathrm{SO}_{2}$ absorption at shorter wavelengths but we were unable to improve the fit.

Analysis of the December 2003 spectral data was identical to that used by Oppenheimer et al. (2005) so as to enable a rigorous comparison. Two fit windows were used, with the first covering the range of strongest $\mathrm{SO}_{2}$ absorption $(309.2-334.5 \mathrm{~nm})$, and the second tuned to detect $\mathrm{NO}_{2}(330.7-349.0 \mathrm{~nm})$.

\section{Results}

\subsection{First estimation of $\mathrm{BrO}$}

We report the first observation of $\mathrm{BrO}$ in the gas plume emitted from Erebus volcano on 3 December 2005. The prevailing conditions were light wind and a cloud-free sky. An example of the DOAS fit for various species is shown in Fig. 1. Time-series of retrieved $\mathrm{SO}_{2}$ and $\mathrm{BrO}$ slant column amounts (SCA) show a strong correlation (Fig. 2). The linear regression gives a $\mathrm{BrO} / \mathrm{SO}_{2}$ molecular ratio of $2.5 \times 10^{-4}$ (correlation coefficient $R^{2}=0.71$ ). Mean errors on column amounts displayed in Fig. 2 only include those associated to the non-linear fit performed in the DOAS retrieval ( [Stutz and Platt, 1996] and [Hausmann et al., 1999] ). Additional errors in column amounts are linked to scattering of light by air molecules and particles in and around volcanic plumes ( [Millan, 1980] , [Platt et al., 1997] , [Mori et al., 2006] and [Kern et al., 2010] ). However, using the same fit window for both absorbers, the radiative transfer related errors similarly affect $\mathrm{BrO}$ and $\mathrm{SO}_{2} \mathrm{SCA}$ and thus tend to cancel in their ratio. Some scatter in the $\mathrm{BrO}$ vs. $\mathrm{SO}_{2} \mathrm{SCA}$ plot can result from variations in the plume chemistry related to the dynamics of magma degassing at Erebus (Oppenheimer et al., 2009).

$\mathrm{BrO}$ was not detected on 4 other days of observations. As detailed in Table 3, assuming a molecular $\mathrm{BrO} / \mathrm{SO}_{2}$ ratio of $2.5 \times 10^{-4}$, the maximum $\mathrm{BrO}$ column amounts expected during these days are well below the detection limit of our DOAS analysis. The main challenge in detecting $\mathrm{BrO}$ at Erebus results from a comparatively low overall flux of sulfur and halogens. The $\mathrm{SO}_{2}$ gas flux is typically below $1.0 \mathrm{~kg} \mathrm{~s}^{-1}$ (Sweeney et al., 2008) while $\mathrm{HCl}$ and $\mathrm{HF}$ fluxes are both in the region of $0.24 \mathrm{~kg} \mathrm{~s}^{-1}$ (Oppenheimer and Kyle, 2008). Given that $\mathrm{SO}_{2}$ SCA above $10^{18}$ molec $\mathrm{cm}^{-2}$, as observed on 3 December 2005, are rarely observed, and indeed are typically below $5 \times 10^{17}$ molec $\mathrm{cm}^{-2}$, the expected BrO column amount should typically be below $1.3 \times 10^{14}$ molec $\mathrm{cm}^{-2}$, corresponding to a hardly detectable amount (see Table 1).

The $\mathrm{BrO} / \mathrm{SO}_{2}$ ratio at Erebus is substantial but not the highest recorded (Table 1), ranking below those observed at the arc volcanoes of Soufrière Hills (Montserrat), Sakurajima (Japan) and Ambrym (Vanuatu). However, $\mathrm{BrO} / \mathrm{SO}_{2}$ ratios at Erebus could be up to an order of magnitude higher at greater distances from the source, as shown by modeling studies of plume 
atmospheric chemistry ( [Bobrowski et al., 2007] and [Roberts et al., 2009] ). The plume BrO abundance is expected initially to increase with distance from source (see Fig. 5) reflecting its photochemical production and mixing with background air and consequent reaction with tropospheric ozone ( [Oppenheimer et al., 2006] , [Bobrowski et al., 2007] and [Roberts et al., 2009] ). Indeed, the experiment presented in this study samples a young plume ( 3-7 min after emission from the lava lake).

The high $\mathrm{BrO} / \mathrm{SO}_{2}$ ratio of the Erebus plume probably corresponds to the magma composition, but it is hard to be sure as it is also strongly controlled by atmospheric processing. The phonolitic magma at Erebus is enriched in $\mathrm{F}$ and $\mathrm{Cl}$ compared to $\mathrm{S}$, which is removed by crystal fractionation during the evolution of the magma (Kyle et al., 1992). As a result, the gas emitted by Erebus has high $\mathrm{HCl} / \mathrm{SO}_{2}$ and $\mathrm{HF} / \mathrm{SO}_{2}$ mass ratios of $0.28-0.92$ and 0.18-0.53 respectively ( [Zreda-Gostynska et al., 1997] , [Wardell et al., 2008] and [Oppenheimer and Kyle, 2008] ). These are amongst the highest in the world (Pyle and Mather, 2009).

\subsection{Nitrogen dioxide}

We did not detect $\mathrm{NO}_{2}$ in any DOAS observations in 2005 (Fig. 1). The presence of $\mathrm{NO}_{2}$ in ultraviolet spectra collected at Erebus on 11 December 2003 (Oppenheimer et al., 2005) is reexamined. At the time of this publication, the correction of the Ring effect was not commonly included in DOAS analysis. However, Vountas et al. (1998) showed that this correction is required for the DOAS retrieval of trace gas species when using scattered solar radiation as a light source for the measurements. The Ring effect is caused by rotational Raman light scattering and leads to a reduction or "filling-in" of the observed optical densities of solar Fraunhofer lines (Grainger and Ring, 1962). This effect strongly depends on the atmospheric light path (Fish and Jones, 1995). We show here that including the Ring spectrum in the DOAS retrieval decreases significantly the estimated $\mathrm{NO}_{2}$ abundances.

We re-examined the 11 December 2003 data (set B) using the same fit window 330.7$349.0 \mathrm{~nm}$ as Oppenheimer et al. (2005), with identical retrieval parameters but including the Ring spectrum in the fit scenario. As illustrated by the fit of a spectrum with a high $\mathrm{SO}_{2} \mathrm{SCA}$ (Fig. 3), taking into account the Ring effect in the modeling decreases the standard deviation of the fit residual by a factor two $\left(1.3 \times 10^{-3}\right.$ versus $\left.2.6 \times 10^{-3}\right)$. Furthermore, the $\mathrm{NO}_{2}$ fit spectrum shows no evidence of the presence of $\mathrm{NO}_{2}$, with an amplitude significantly smaller than the one of the fit residual. As illustrated in Figure $\mathrm{S}-1, \mathrm{NO}_{2}$ slant column amounts are always below the $\mathrm{NO}_{2}$ detection limit of $4 \times 10^{16}$ molec $\mathrm{cm}^{-2}$. In addition, the correlation between $\mathrm{NO}_{2}$ and $\mathrm{SO}_{2}$ time-series disappears. Consequently, the presence of large amounts of $\mathrm{NO}_{2}$ on 11 December 2003 is an artifact of the DOAS analysis of Oppenheimer et al. (2005).

The $\mathrm{NO}_{2}$ cross-section presents great similarities with the Ring spectrum, as underlined by Vountas et al. (1998), and the Ring effect can be confused with $\mathrm{NO}_{2}$ absorption if not corrected. Results of DOAS analysis performed by Oppenheimer et al. (2005) were particularly sensitive to this, as the version of the DOASIS software used at that time was not properly removing low frequency components of spectra. In addition, the Ring effect is strongly modulated by the presence of the volcanic cloud. Indeed, the existence of an aerosolrich plume leads to a decrease of the light received by the spectrometer, as illustrated in the upper plot of Fig. S-1 by the anti-correlation between $\mathrm{SO}_{2}$ and light intensity. Simultaneously, the light path length is increased by multiple light scattering in the plume, implying a larger Raman scattering due to a greater number of collisions of light photons with air molecules. 
These processes, affecting both light intensity and Raman scattering magnitude, explain a significant increase of the Ring effect due to the plume (de Beek et al., 2001). As a consequence, the Ring is highly correlated to the $\mathrm{SO}_{2}$ abundance, as shown in Fig. S-1 (upper and lower plots). This explains the spurious correlation of $\mathrm{NO}_{2}$ and $\mathrm{SO}_{2}$ time-series found by Oppenheimer et al. (2005) when not correcting for the Ring effect.

According to our analysis, the amount of $\mathrm{NO}_{2}$ in the plume has to be lower than $2 \times 10^{16}$ molec $\mathrm{cm}^{-2}$ on 3 December 2005 . This value corresponds to the limit of detection of our analysis, estimated from a fit residual with a standard deviation of $1.0 \times 10^{-3}$ (see Fig. 1) and a peak-to-peak amplitude of the differential $\mathrm{NO}_{2}$ cross-section at its strongest peaks of absorption in the 310.9-377.8 $\mathrm{nm}$ fit window of $1.0 \times 10^{-19} \mathrm{~cm}^{2} \mathrm{molec}^{-1}$. Assuming a correlation between $\mathrm{SO}_{2}$ and $\mathrm{NO}_{2}$ variations, we expect to record the highest $\mathrm{NO}_{2}$ abundance when the highest $\mathrm{SO}_{2}$ abundance is observed. This would yield a molecular $\mathrm{NO}_{2} / \mathrm{SO}_{2}$ ratio lower than 0.012 , based on the highest $\mathrm{SO}_{2}$ column amount of $1.7 \times 10^{18} \mathrm{molec} \mathrm{cm}^{-2}$. This ratio, representing already an upper bound, is smaller by one order of magnitude than reported by Oppenheimer et al. (2005).

Note that HONO was not detected in any of the ultraviolet spectra.

\section{Discussion}

\subsection{Dynamics of the BrO explosion}

Combined gas and particulate analyses from filter pack measurements performed in December-January of 1986/87, 1988/89, 1989/90, 1991/92 at the crater rim indicated a Br/S mass concentration ratio of $2-4 \times 10^{-3}$ (Zreda-Gostynska et al., 1997). If we assume the same $\mathrm{Br}$ content in the plume at the crater rim in December 2005, and no loss of $\mathrm{SO}_{2}$ in the plume, we can estimate from the $\mathrm{Br} / \mathrm{S}$ mass ratio of $6 \times 10^{-4}$ (deduced from molecular $\mathrm{BrO} / \mathrm{SO}_{2}$ ) that $15-30 \%$ of the total available $\mathrm{Br}$ at the crater rim (i.e. the sum of $\mathrm{HBr}$ gas phase and particulate $\mathrm{Br}$, both sampled with filter packs) is converted in $\mathrm{BrO}$ in about $1-3 \mathrm{~min}$, i.e. the time for plume to travel from crater rim, at a distance of $\sim 225 \mathrm{~m}$ from the lava lake (Csatho et al., 2008), to the $400 \mathrm{~m}$ high DOAS field of view assuming a vertical plume speed in 1$2.5 \mathrm{~m} \mathrm{~s}^{-1}$ (Boichu et al., 2010). The plume is only $\sim 3-7 \mathrm{~min}$ old at the altitude of the DOAS field of view where $\mathrm{BrO}$ is measured. Note that we consider in this estimation $\mathrm{HBr}$ to be the most abundant gas phase $\mathrm{Br}$ species, neglecting the presence of $\mathrm{BrNO}_{2}$ (and/or $\mathrm{BrONO}_{2}$ ), $\mathrm{BrO}, \mathrm{Br}_{2(g)}$ and $\mathrm{Br}_{(g)}$ at the crater rim given the very young plume age, which is consistent with the Br speciation modeled by von Glasow (2010). So, despite low atmospheric temperature and a plume absolute humidity which may be low, the autocatalytic heterogeneous oxidation of source $\operatorname{HBr}_{(g)}$ is very rapid on 3 December 2005, similarly to estimates at Etna with $40 \%$ of $\mathrm{HBr}_{(g)}$ transformed into $\mathrm{BrO}$ in a 3-4 min plume age (Oppenheimer et al., 2006). The high abundance of $\mathrm{HCl}$ may help the partitioning of $\mathrm{HBr}$ from the gas to the aerosol phase (Oppenheimer et al., 2006), as demonstrated by the relatively high aerosol $\mathrm{Br}^{-}$content with a $\mathrm{Br}^{-} / \mathrm{SO}_{4}{ }^{2-}$ molar ratio in $0.022-0.028$ for December 2006 and 2007 (Ilyinskaya et al., 2010).

The formation of $\mathrm{HNO}_{3}$ and $\mathrm{HO}_{2} \mathrm{NO}_{2}$ observed in the downwind plume cannot result from the incorporation of background $\mathrm{NO}_{x}$ into the plume during its dispersion, given the very low levels of pollution or other $\mathrm{NO}_{x}$ sources in the Antarctic troposphere. Thus, this finding suggests conversion of volcanogenic $\mathrm{NO}_{x}$ very early in the plume's history, i.e. probably at the lava lake. As shown by Roberts et al. (2009), $\mathrm{HNO}_{3}$ may be formed in a dispersing plume 
via the BrO-mechanism $\left(\mathrm{BrO}+\mathrm{NO}_{2} \rightarrow \mathrm{BrONO}_{2}\right.$ then $\mathrm{BrONO}_{2}+\mathrm{HBr}_{a q} \rightarrow \mathrm{Br}_{2}+\mathrm{HNO}_{3}$; actually a parameterization of a multi-stage aerosol-phase processes involving

$\mathrm{BrONO}_{2}+\mathrm{H}_{2} \mathrm{O} \rightarrow \mathrm{HOBr}+\mathrm{HNO}_{3}$ and $\mathrm{HOBr}_{(a q)}+\mathrm{HBr} \rightarrow \mathrm{Br} 2+\mathrm{H}_{2} \mathrm{O}$ ), at a rate much faster than via the $\mathrm{OH}$ radical mechanism (see Fig. 5). Alternatively, $\mathrm{HNO}_{3}$ could be produced via the $\mathrm{OH}$ mechanism and/or from $\mathrm{HO}_{2} \mathrm{NO}_{2}$, which is itself generated from $\mathrm{NO}_{2}+\mathrm{HO}_{2} \rightarrow \mathrm{HO}_{2} \mathrm{NO}_{2}$. The presence of elevated in-plume $\mathrm{HO}_{2} \mathrm{NO}_{2}$ reported by Oppenheimer et al., (2010) supports the high-temperature formation of $\mathrm{NO}_{x}$ and $\mathrm{HO}_{x}$, indicating that these reactions most likely occur near the lava lake.

\subsection{In-plume reactive bromine chemistry and ozone depletion}

Oppenheimer et al. (2010) reported on airborne intercepts of the Erebus plume on 9 and 10 December 2005 (i.e. the same period as the observations of BrO reported here). Analyses of major and trace volcanic gases, collected with an integration time of $1 \mathrm{~min}$ (corresponding to $\sim 4 \mathrm{~km}$ of flight line), at distances ranging from 1 to $56 \mathrm{~km}$ from the crater were reported. $\mathrm{O}_{3}$ depletion, up to $35 \%$ relatively to background level, was observed for a plume age in $4-6 \mathrm{~h}$ (Figure S-2).

DOAS spectrometers also measure the ozone abundance but, contrary to aircraft measurements, it is integrated over a long light path crossing a large part of atmosphere from the sun to the instrument. The negative values of the $\mathrm{O}_{3}$ column amounts estimated by DOAS (Fig. 1 and Fig. 3) do not indicate ozone depletion in the plume relatively to the background, but are an artifact of the DOAS method. Indeed, we observe an apparent depletion of $\sim 10^{+18}$ molec $\mathrm{cm}^{-2}$ of ozone in the plume. Given a background $\mathrm{O}_{3}$ concentration of $\sim 0.025$ ppmv (Oppenheimer et al., 2010), this would correspond to a complete ingestion of background $\mathrm{O}_{3}$ by the plume over a distance of $16 \mathrm{~km}$, which is irrelevant. Consequently, the negative column amounts of $\mathrm{O}_{3}$, but also $\mathrm{O}_{4}$, result from a shorter light path, crossing less atmospheric $\mathrm{O}_{3}$ and $\mathrm{O}_{4}$, when the plume is in the DOAS field of view.

Based upon modeling studies of Bobrowski et al. (2007) and Roberts et al. (2009), the amounts of $\mathrm{HBr}_{(g)}$ (with a $\mathrm{HBr} / \mathrm{SO}_{2}$ molar ratio ranging in $6 \pm 2 \times 10^{-4}$ calculated from ZredaGostynska (1995)) and BrO [This study] measured at Erebus may be sufficient to cause the episode of ozone depletion up to $35 \%$ of the background level observed in the plume (see Table 4 for a summary of all observations of volatile species, in gas and particle phases, available at Erebus). Fig. 5 illustrates the impact of plume reactive halogen chemistry on ambient ozone. Observation of $\mathrm{O}_{3}$ depletion at great distance at Erebus (26-39 km or 4-6 h) highlights the dynamics of this phenomenon with plume age/distance. Both chemical reactions and plume dispersion play a role in plume reactive halogen chemistry.

Consequently, models describing plume evolution require various input parameters including the chemical composition and strength of gas emissions at source, the aerosol load and dispersion parameters of the plume. According to a sensitivity study of these parameters developed by Roberts (2009), the magnitude of the depletion of $\mathrm{O}_{3}$ at $\sim 30 \mathrm{~km}$ observed by Oppenheimer et al. (2010) can be predicted for high gas flux and/or atmospheric conditions leading to inefficient plume mixing with ambient air. The high gas flux hypothesis can be readily discarded, as the flux of volcanic gases measured at Erebus $\left(\mathrm{SO}_{2}\right.$ flux $\left.\leq 1 \mathrm{~kg} \mathrm{~s}^{-1}\right)$ is low compared to most actively degassing volcanoes. On the other hand, the noticeably low wind speed of $1.8 \mathrm{~m} \mathrm{~s}^{-1}$, with nevertheless little plume dispersion shown by pictures taken the same day (Oppenheimer et al., 2010), may provide conditions favorable to a sustained depletion on long distances, assuming sufficient bromine is available at source. Less mixing with background air leads to a highly concentrated plume and a slower replacement of 
destroyed ozone. Eventually, this observation suggests that aerosol load, needed to allow heterogeneous reactions fundamentally involved in the reactive bromine chemical cycle, is not a limiting factor at Erebus. The noteworthy small size of Erebus aerosols, in the range of the Greenfield gap 0.01-1 $\mu \mathrm{m}$, (Radke, 1982), likely inherited from low atmospheric temperature and humidity, assures them an exceptionally long life which may be a crucial ingredient for this long-range impact of the plume.

\subsection{Dynamics of $\mathrm{NO}_{\mathrm{x}}$ conversion and impact on reactive bromine chemistry}

\subsubsection{Observations}

In-situ measurements in the distal plume $(1-56 \mathrm{~km})$ detected the presence of $\mathrm{NO}_{y}$ species $\left(\mathrm{HNO}_{3}\right.$ and $\left.\mathrm{HO}_{2} \mathrm{NO}_{2}\right)$, with a noticeably stable $\left[\mathrm{HNO}_{3}+\mathrm{HO}_{2} \mathrm{NO}_{2}\right] / \mathrm{SO}_{2}$ molar ratio of $\sim 0.03$ (Oppenheimer et al., 2010). As illustrated in Fig. 5, these nitrogen species originate from reactions of $\mathrm{NO}_{x}$ with either $\mathrm{OH}$ or $\mathrm{HO}_{2}$ radicals (Martin et al., 2006), or via the involvement of reactive halogen species ( [Oppenheimer et al., 2006] and [Roberts et al., 2009] ). $\mathrm{NO}_{x}$ species are assumed to form by thermal fixation of atmospheric background $\mathrm{N}_{2}$ at the hot lava lake surface ( [Huebert et al., 1999] and [Mather et al., 2004a] ) and/or through mixing of hot magmatic gases and ambient air (Martin et al., 2006). Previous estimations of $\mathrm{NO}_{2} / \mathrm{SO}_{2}$ of $\sim 0.1$ a few hundreds meters above the crater by Oppenheimer et al. (2005) were not consistent with the levels of $\mathrm{NO}_{y}$ observed in the downwind plume. This suggested the storage of some nitrogen "in excess", as aerosol nitrate $\mathrm{NO}_{3}{ }^{-}$and/or in the form of gas phase halo-nitrates (Oppenheimer et al., 2010). From our re-evaluation of $\mathrm{NO}_{2}$ abundance near the crater presented in this study, i.e. $\mathrm{NO}_{2} / \mathrm{SO}_{2} \leq 0.012$, and assuming that $\mathrm{NO}$ and $\mathrm{NO}_{2}$ abundances would be comparable (Mather et al., 2004b), it is no longer necessary to invoke "excess" nitrogen species to explain the observations. This conclusion is also consistent with the insignificant quantities of nitrate that have been observed in near vent aerosols collected using a cascade impactor at the crater rim of Erebus (Ilyinskaya et al., 2010). Moreover, because our DOAS detection limit provides an upper bound of the $\mathrm{NO}_{2}$ abundance, this tends to support the rapid conversion of $\mathrm{NO}_{x}$ into $\mathrm{HNO}_{3}$ and $\mathrm{HO}_{2} \mathrm{NO}_{2}$ by oxidation in the cooling plume. This result is in agreement with the absence of any $\mathrm{NO}_{x}$ in the downwind plume (Oppenheimer et al., 2010), and in-situ observations by Mather et al. (2004b) in the plume of Masaya volcano. In contrast with the typical tropospheric lifetime of $\mathrm{NO}_{x}$ of a few days, a volcanic plume may provide significant quantities of $\mathrm{HO}_{x}$ radicals to promote much faster oxidation (Gerlach, 2004).

The size and continuous overturning of the lava lake at Erebus, whose temperature has been estimated at around $1000^{\circ} \mathrm{C}$ and which has an area of order $1000 \mathrm{~m}^{2}$ (Kelly et al., 2008), may make it a significant $\mathrm{NO}_{x}$ source compared to volcanoes with comparatively small vents (such as Masaya). It has been speculated that a high abundance of $\mathrm{NO}_{x}$ in a young plume could promote the cycles that form reactive bromine from $\mathrm{HBr}$, but also titrate away the $\mathrm{BrO}$, by converting it (once formed) to $\mathrm{BrNO}_{2}$ (von Glasow, 2010) or $\mathrm{BrONO}_{2}$ (Roberts, 2009). However, at Erebus, we have identified appreciable quantities of $\mathrm{BrO}$ just a few hundred meters above the lava lake (plume age of 3-7 min), with 15-30\% of total $\mathrm{Br}$ available at the crater rim already consumed to form $\mathrm{BrO}$ (Fig. 5). Rapid oxidation of $\mathrm{NO}_{x}$ species may again be the key to explain why the $\mathrm{BrO}$ explosion does not seem evidently to be perturbed. As developed in the next section, model simulations add weight to this hypothesis but also 
suggest that this conversion of $\mathrm{NO}_{x}$ is even more rapid than could be gauged from DOAS observations.

\subsubsection{Model simulations}

Numerical simulations, based on the PlumeChem model described by Roberts et al. (2009), were performed to investigate the impact of volcanic $\mathrm{NO}_{x}$ emissions at source on the subsequent formation of $\mathrm{BrO}$ in the plume of Erebus. As shown in Fig. 4, simulations with an initial $\mathrm{NO}_{2} / \mathrm{SO}_{2}=1$ (corresponding approximately to the ratio reported by Oppenheimer et al., 2005 ) result in extremely low $\mathrm{BrO} / \mathrm{SO}_{2}$ in contradiction with our observations. Whenever $\mathrm{BrO}$ is formed, among other reactions, it can rapidly react with $\mathrm{NO}_{2}$ to form $\mathrm{BrONO}_{2}$ according to the reaction $\left(\mathrm{BrO}+\mathrm{NO}_{2} \rightarrow \mathrm{BrONO}_{2}\right)$, thereby titrating $\mathrm{BrO}$ at high $\mathrm{NO}_{2}$ concentrations. This is entirely consistent with our reinterpretation of the abundance of $\mathrm{NO}_{2}$ in the young plume of Erebus. The simulations also show that $\mathrm{BrO} / \mathrm{SO}_{2}$ only matches the observed ratio of $2.4 \times 10^{-4}$ at Erebus, for a 3-7 min old plume, if $\mathrm{NO}_{x}$ species are essentially absent (or at least $\mathrm{NO}_{2} / \mathrm{SO}_{2}<0.012$ ).

\section{Conclusions}

Since the first observation of $\mathrm{BrO}$ in a volcanic plume, the potential for ozone depletion has been discussed (Bobrowski et al., 2003). The plausibility of the hypothesis has then been reinforced by modeling studies of atmospheric plume chemistry involving reactive halogen and nitrogen species (_[Oppenheimer et al., 2006] , [Bobrowski et al., 2007] and [Roberts et al., 2009] ). Ozone depletion has been reported in association with elevated levels of $\mathrm{HCl}$ in the stratospheric plume erupted from Hekla volcano during polar winter of 2000 ( [Rose et al., 2006]_and [Millard et al., 2006]_). Our study, in combination with that of Oppenheimer et al. (2010), provides the first evidence of $\mathrm{BrO}$ formation during a period of quiescent degassing of Erebus in the polar summer, coincident with ozone destruction in the distal tropospheric plume.

This is also the first estimation of $\mathrm{BrO}$ abundance at a phonolitic volcano (Erebus being the only one currently active on Earth). $\mathrm{A} \mathrm{BrO} / \mathrm{SO}_{2}$ ratio of $2.5 \times 10^{-4}$ is evaluated for a young plume age (3-7 min). This highlights a high proportion of bromine relative to sulfur, which is consistent with the high halogen abundance observed at Erebus and particularly high $\mathrm{HCl} / \mathrm{SO}_{2}$ and $\mathrm{HF} / \mathrm{SO}_{2}$ ratios in the atmospheric plume.

$\mathrm{NO}_{x}$ generation at volcanoes hosting large, hot lava lakes should be substantial according to conceptual models for its formation. In an earlier study, Oppenheimer et al. (2005) had reported high abundances of $\mathrm{NO}_{2}$ in the young plume of Erebus based on DOAS evaluations. We have re-examined the same dataset, which was collected on 11 December 2003, and been unable to reproduce the original finding. However, the detection limit of our new analysis fixes an upper bound for $\mathrm{NO}_{2}$ abundance which suggests a ratio of $\mathrm{NO}_{2} / \mathrm{SO}_{2} \leq 0.012$, an order of magnitude less than previously estimated. This reassessment shows that the amount of $\mathrm{NO}_{y}$ $\left(\mathrm{HNO}_{3}\right.$ and $\mathrm{HO}_{2} \mathrm{NO}_{2}$ here), detected in the distal plume by Oppenheimer et al. (2010), can be explained by conversion of early-formed volcanic $\mathrm{NO}_{x}$. It no longer points to the presence of nitrate in aerosol or in the form of gas phase halo-nitrates as had been speculated. This reevaluation of $\mathrm{NO}_{2}$ abundance is also consistent with a rapid conversion of $\mathrm{NO}_{x}$ to $\mathrm{NO}_{y}$. Model simulations support the idea that the $\mathrm{BrO} / \mathrm{SO}_{2}$ ratio observed in the young plume of Erebus cannot be explained without early oxidation of $\mathrm{NO}_{x}$ emissions very close to the lava lake. 
Finally, we estimated a molar $\mathrm{HBr} / \mathrm{SO}_{2}$ ratio of $6 \pm 2 \times 10^{-4}$ at the crater rim and a $\mathrm{BrO} / \mathrm{SO}_{2}$ ratio of $2.5 \times 10^{-4}$ at $\sim 400 \mathrm{~m}$ above the lake, which corresponds to a plume age of 3-7 min. Given a typical $\mathrm{SO}_{2}$ flux of $0.7 \pm 0.3 \mathrm{~kg} \mathrm{~s}^{-1}$ (Sweeney et al., 2008), recent modeling studies of reactive plume halogen and nitrogen chemistry ([Bobrowski et al., 2007]_and [Roberts et al., 2009]_) suggest that these values can account for the observed magnitude of $\mathrm{O}_{3}$ depletion in the Erebus plume. The fact that $\mathrm{O}_{3}$ depletion was observed in a plume about $30 \mathrm{~km}$ from the source supports limited further entrainment of background air to replace the consumed ozone. The particularly low wind speed during the period in which the aircraft measurements were made was probably conducive to this stability of the plume. The continental scale range of the Erebus plume has already been demonstrated and implicated by a range of observations and models (see Section 1). In future, further simulations of plume chemistry that account for the presence of reactive halogen and nitrogen species, should help to evaluate the actual overall impact of Erebus on the Antarctic troposphere. As illustrated in our study, atmospheric conditions likely play an important role, as of course will the seasonality of photochemical processes.

\section{Acknowledgments}

We gratefully acknowledge support from NSF Office of Polar Programs grants ANT-0538414 and ANT-0838817 and the United States Antarctic Program. We thank Caroline Fayt and Michel Van Roozendael for developing and providing the WinDOAS software as well as giving judicious advice concerning its use. MB thanks the EU Framework 6 and 7 programmes which supported the NOVAC and MIAVITA projects for her research grants. $\mathrm{CO}$ additionally thanks the NERC, for support via the National Center for Earth Observation. TJR acknowledges support from EU project NSINK. CO and PK are warmly grateful to their companions in Science Event G-081 and the helicopter pilots, and RPSC staff based at McMurdo Station. They particularly thank Dr. Tom Wagner and Dr. Alex Isern, former and present Program Managers at NSF, for support. Finally, we thank two anonymous reviewers for their comments and suggestions which allowed to greatly improve the manuscript.

\section{References}

Bani et al., 2009 P. Bani, C. Oppenheimer, V. Tsanev, S. Carn, S. Cronin, R. Crimp, J. Calkins, D. Charley, M. Lardy and T. Roberts, Surge in sulphur and halogen degassing from Ambrym volcano, Vanuatu. Bulletin of Volcanology, 7110 (2009), pp. 1159-1168

Bobrowski et al., 2003 N. Bobrowski, G. Honninger, B. Galle and U. Platt, Detection of bromine monoxide in a volcanic plume. Nature, 423 (2003), pp. 273-277.

Bobrowski and Platt, 2007 N. Bobrowski and U. Platt, $\mathrm{SO}_{2} / \mathrm{BrO}$ ratios studied in five volcanic plumes. Journal of Volcanology and Geothermal Research, 166 (2007), pp. 147-160.

Bobrowski et al., 2007 N. Bobrowski, R. von Glasow, A. Aiuppa, S. Inguaggiato, I. Louban, O. Ibrahim and U. Platt, Reactive halogen chemistry in volcanic plumes. Journal of Geophysical Research, 112 D06311 (2007).

Bogumil et al., 2003 K. Bogumil, J. Orphal, T. Homann, S. Voigt, P. Spietz, O. Fleischmann, A. Vogel, M. Hartmann, H. Kromminga, H. Bovensmann, J. Frerick and J. Burrows, Measurements of molecular absorption spectra with the SCIAMACHY pre-flight model: instrument characterization and reference data for atmospheric remote-sensing in the 230- 
$2380 \mathrm{~nm}$ region. Journal of Photochemistry and Photobiology A: Chemistry, 157 (2003), pp. $167-184$.

Boichu et al., in preparation Boichu, M., Oppenheimer, C., Roberts, T. Why some arc andesitic volcanoes emit less halogens into the atmosphere than others?, in preparation..

Boichu et al., 2010 M. Boichu, C. Oppenheimer, V. Tsanev and P. Kyle, High temporal resolution $\mathrm{SO}_{2}$ flux measurements at Erebus volcano, Antarctica. Journal of Volcanology and Geothermal Research, 190 (2010), pp. 325-336.

Chuan, 1994 R. Chuan, Dispersal of volcano-derived particles from Mount Erebus in the Antarctic atmosphere, Antarctic Research Series, vol. 66 ,in: P. Kyle, Editor, Volcanological and Environmental Studies of Mount Erebus, Antarctica, American Geophysical Union (1994), pp. 97-102.

Chuan et al., 1986 R. Chuan, J. Palais, W. Rose and P. Kyle, Fluxes, sizes, morphology and compositions particles in the Mt. Erebus volcanic plume, December 1983. Journal of Atmospheric Chemistry, 4 (1986), pp. 467-477.

Csatho et al., 2008 B. Csatho, T. Schenk, P. Kyle, T. Wilson and W. Krabill, Airborne laser swath mapping of the summit of Erebus volcano, Antarctica: applications to geological mapping of a volcano. Journal of Volcanology and Geothermal Research, 1773 (2008), pp. 531-548.

David et al., 2010 C. David, P. Keckhut, A. Armetta, J. Jumelet, M. Snels, M. Marchand and S. Bekki, Radiosonde stratospheric temperatures at Dumont d'Urville (Antarctica): trends and link with polar stratospheric clouds. Atmospheric Chemistry and Physics, 10 (2010), pp. 3813-3825.

de Beek et al., 2001 R. de Beek, M. Vountas, V. Rozanov, A. Richter and J. Burrows, The Ring effect in the cloudy atmosphere. Geophysical Research Letters, 284 (2001), pp. 721 724

Fish and Jones, 1995 D. Fish and R. Jones, Rotational Raman scattering and the Ring effect in zenith-sky spectra. Geophysical Research Letters, 22 (1995), pp. 811-814.

Fleischmann et al., 2004 O. Fleischmann, M. Hartmann, J. Burrowsa and J. Orphal, New ultraviolet absorption cross-sections of $\mathrm{BrO}$ at atmospheric temperatures measured by timewindowing Fourier transform spectroscopy. Journal of Photochemistry and Photobiology A: Chemistry, 168 (2004), pp. 117-132.

Gerlach, 2004 T.M. Gerlach, Volcanic sources of tropospheric ozone-depleting trace gases. Geochemistry Geophysics Geosystems, 5 Q09007 (2004).

Giggenbach et al., 1973 W.F. Giggenbach, P.R. Kyle and G.L. Lyon, Present volcanic activity on Mount Erebus, Ross Island, Antarctica. Geology, 1 (1973), pp. 135-136.

Graf et al., 2010 H. Graf, S. Shirsat, C. Oppenheimer, M. Jarvis, R. Podzun and D. Jacob, Continental scale Antarctic deposition of sulphur and black carbon from anthropogenic and volcanic sources. Atmospheric Chemistry and Physics, 10 (2010), pp. 2457-2465. 
Grainger and Ring, 1962 J. Grainger and J. Ring, Anomalous Fraunhofer line profiles. Nature, 193 (1962), p. 762

Halmer et al., 2002 M. Halmer, H.-U. Schminke and H.-F. Graf, The annual volcanic gas input into the atmosphere, in particular into the stratosphere: a global data set for the past 100 years. Journal of Volcanology and Geothermal Research, 115 (2002), pp. 515-528.

Hausmann et al., 1999 M. Hausmann, U. Brandenburger, T. Brauers and H. Dorn, Simple Monte Carlo methods to estimate the spectra evaluation error in differential optical absorption spectroscopy. Applied Optics, 383 (1999), pp. 462-475

Hermans , 2002 C. Hermans, Measurement of absorption cross sections and spectroscopic molecular parameters: $\mathrm{O}_{2}$ and its collisonal induced absorption (2002).

Hobbs et al., 1991 P. Hobbs, L. Radke, J. Lyons, R. Ferek and D. Coffman, Airborne measurements of particle and gas emissions from the 1990 volcanic eruptions of Mount Redoubt. Journal of Geophysical Research, 96 D10 (1991), pp. 18735-18752.

Hobbs et al., 1982 P. Hobbs, J. Tuell, D. Hegg, L. Radke and L. Eltgrowth, Particles and gases in the emissions from the 1980-1981 volcanic eruptions of Mt. St. Helens. Journal of Geophysical Research, 87 (1982), pp. 11062-11086.

Huebert et al., 1999 B. Huebert, P. Vitousek, J. Sutton, T. Elias, J. Heath, S. Coeppicus, S. Howell and B. Blomquist, Volcano fixes nitrogen into plant-available forms.

Biogeochemistry, 47 (1999), pp. 111-118

Ilyinskaya et al., 2010 E. Ilyinskaya, C. Oppenheimer, T. Mather, R. Martin and P. Kyle, Size-resolved chemical composition of aerosol emitted by Erebus volcano, Antarctica. Geochemistry Geophysics Geosystems, 113 (2010), p. Q03017

Kelly et al., 2008 P. Kelly, P. Kyle, N. Dunbar and K. Sims, Geochemistry and mineralogy of the phonolite lava lake, Erebus volcano, Antarctica: 1972-2004 and comparison with older lavas. Journal of Volcanology and Geothermal Research, 177 (2008), pp. 589-605.

Kern et al., 2010 C. Kern, T. Deutschmann, L. Vogel, M. Wohrbach, T. Wagner and U. Platt, Radiative transfer corrections for accurate spectroscopic measurements of volcanic gas emissions. Bulletin of Volcanology, 722 (2010), pp. 223-247.

$\underline{\text { Kern et al., } 2009}$ C. Kern, H. Sihler, L. Vogel, C. Rivera, M. Herrera and U. Platt, Halogen oxide measurements at Masaya Volcano, Nicaragua using active long path differential optical absorption spectroscopy. Bulletin of Volcanology, 716 (2009), pp. 659-670.

Kraus, 2006 Kraus, S.G., 2006. DOASIS: a framework design for DOAS. Ph.D. Thesis, University of Heidelberg, Germany..

Kyle et al., 1992 P. Kyle, J. Moore and M. Thirlwall, Petrologic evolution of anorthoclase phonolite lavas at Mount Erebus, Ross Island, Antarctica. Journal of Petrology, 33 (1992), pp. 849-875 


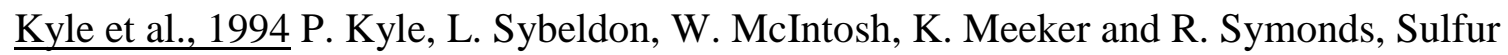
dioxide emission rates from Mount Erebus, Antarctica, Volcanological and Environmental Studies of Mount Erebus, Antarctica, vol. 213 ,in: P.R. Kyle, Editor, American Geoophysical Union, Washington, D.C (1994), pp. 69-82

Kyle et al., 1982 P.R. Kyle, R.R. Dibble, W.F. Giggenbach and J. Keys, Volcanic activity associated with the anorthoclase phonolite lava lake, Mount Erebus, Antarctica Antarctic Geoscience, University of Wisconsin Press, Madison (1982), pp. 734-745.

Lee et al., 2005 C. Lee, Y. Kim, H. Tanimoto, N. Bobrowski, U. Platt, T. Mori, K. Yamamoto and C. Hong, High $\mathrm{ClO}$ and ozone depletion observed in the plume of Sakurajima volcano, Japan. Geophysical Research Letters, 32 L21809 (2005).

Martin et al., 2006 R.S. Martin, T.A. Mather and D.M. Pyle, High-temperature mixtures of magmatic and atmospheric gases. Geochemistry Geophysics Geosystems, 7 Q04006 (2006).

Mather, 2008 T. Mather, Volcanoes and the atmosphere: the potential role of the atmosphere in unlocking the reactivity of volcanic emissions. Philosophical Transactions A, 366 (2008), pp. 4581-4595

Mather et al., 2004a T. Mather, A. Allen, B. Davison, D. Pyle, C. Oppenheimer and A. McGonigle, Nitric acid from volcanoes. Earth and Planetary Science Letters, 218 (2004), pp. 17-30.

Mather et al., 2004b T. Mather, D. Pyle and A. Allen, Volcanic source for fixed nitrogen in the early Earth's atmosphere. Geology, 32 (2004), pp. 905-908

Meeker et al., 1991 K.A. Meeker, R. Chuan, P. Kyle and J. Palais, Emission of elemental gold particles from Mount Erebus, Ross Island, Antarctica. Geophysical Research

Letters, 18 (1991), pp. 1405-1408.

Mikelich, 2006 Mikelich, S., 2006. Sulfur, chlorine, fluorine and aerosol emissions from Mt. Erebus, Antarctica: December 2003 and December 2004. Master's Thesis, New Mexico Tech University, Socorro, USA..

Millan, 1980 M. Millan, Remote sensing of air pollutants, a study of some atmospheric scattering effects. Atmospheric Environment, 1411 (1980), pp. 1241-1253.

Millard et al., 2006 G. Millard, T. Mather, D. Pyle, W. Rose and B. Thornton, Halogen emissions from a small volcanic eruption: modeling the peak concentrations, dispersion, and volcanically induced ozone loss in the stratosphere. Geophysical Research

Letters, 33 L19815 (2006).

Mori et al., 2006 T. Mori, T. Mori, K. Kazahaya, M. Ohwada, J. Hirabayashi and S. Yoshikawa, Effect of UV scattering on $\mathrm{SO}_{2}$ emission rate measurements. Geophysical Research Letters, 33 L17315 (2006).

Oppenheimer and Kyle, 2008 C. Oppenheimer and P. Kyle, Probing the magma plumbing of Erebus volcano, Antarctica, by open-path FTIR spectroscopy of gas emissions. Journal of Volcanology and Geothermal Research, 177 (2008), pp. 743-754. 
Oppenheimer et al., 2010 C. Oppenheimer, P. Kyle, F. Eisele, J. Crawford, G. Huey, D. Tanner, K. Brady, L. Mauldin, D. Blake, A. Beyersdorf, M. Buhr and D. Davis, Atmospheric chemistry of an Antarctic volcanic plume. Journal of Geophysical Research Atmospheres, 115 D04303 (2010).

Oppenheimer et al., 2005 C. Oppenheimer, P. Kyle, V. Tsanev, A. McGonigle, T. Mather and D. Sweeney, Mt. Erebus, the largest point source of $\mathrm{NO}_{2}$ in Antarctica. Atmospheric Environment, 39 (2005), pp. 6000-6006.

Oppenheimer et al., 2009 C. Oppenheimer, A. Lomakina, P. Kyle, N. Kingsbury and M. Boichu, Pulsatory magma supply to Erebus lava lake, Antarctica. Earth and Planetary Science Letters, 284 (2009), pp. 392-398.

Oppenheimer et al., 2003 C. Oppenheimer, D. Pyle and J.E. Barclay, Geological Society of London (2003), Special Publication.

Oppenheimer et al., 2006 C. Oppenheimer, V. Tsanev, C. Braban, R. Cox, J. Adams, A. Aiuppa, N. Bobrowski, P. Delmelle, J. Barclay and A. McGonigle, BrO formation in volcanic plumes. Geochimica et Cosmochimica Acta, 70 (2006), pp. 2935-2941.

Platt et al., 1997 U. Platt, L. Marquard, T. Wagner and D. Perner, Corrections for zenith scattered light DOAS. Geophysical Research Letters, 2414 (1997), pp. 1759-1762

Platt and Stutz, 2008 U. Platt and J. Stutz, Differential Optical Absorption Spectroscopy: Principles and Applications, Springer, Berlin (2008).

Pyle and Mather, 2009 D. Pyle and T. Mather, Halogens in igneous processes and their fluxes to the atmosphere and oceans from volcanic activity: a review. Chemical Geology, 263 (2009), pp. 110-121.

Radke, 1982 L. Radke, Chlorine, fluorine, and sulfur emissions from Mount Erebus, Antarctica and estimated contributions to the Antarctic atmosphere. Nature, 299 (1982), pp. $710-712$

Roberts, 2009 Roberts, T., 2009. The chemistry of volcanic plumes: reactive halogen formation and ozone depletion. Ph.D. Thesis, University of Cambridge, Chemistry Department..

Roberts et al., 2009 T. Roberts, C. Braban, R. Martin, C. Oppenheimer, J. Adams, R. Cox, R. Jones and P. Griffiths, Modelling reactive halogen formation and ozone depletion in volcanic plumes. Chemical Geology, 263 (2009), pp. 151-163.

Robock and Oppenheimer, 2003 A. Robock and C.E. Oppenheimer, Volcanism and the Earth's atmosphere, Geophysical Monograph, vol. 139 American Geophysical Union, Washington, DC (2003).

Rose et al., 1985 W.I. Rose, R.L. Chuan and P.R. Kyle, Rate of sulphur dioxide emission from Erebus volcano, Antarctica, December 1983. Nature, 316 (1985), pp. 710-712 
Rose et al., 2006 W.I. Rose, G.A. Millard, T.A. Mather, D.E. Hunton, B. Anderson, C. Oppenheimer, B.F. Thornton, T.M. Gerlach, A.A. Viggiano, Y. Kondo, T.M. Miller and J.O. Ballenthin, Atmospheric chemistry of a 33-34 hour old volcanic cloud from Hekla Volcano (Iceland): insights from direct sampling and the application of chemical box modeling. Journal of Geophysical Research, 111 D20206 (2006).

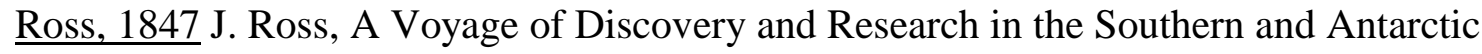
Regions, John Murray, London (1847).

Schumann et al., 2010 U. Schumann, B. Weinzierl, O. Reitebuch, H. Schlager, A. Minikin, C. Forster, R. Baumann, T. Sailer, K. Graf, H. Mannstein, C. Voigt, S. Rahm, R. Simmet, M. Scheibe, M. Lichtenstern, P. Stock, H. Rüba, D. Schäuble, A. Tafferner, M. Rautenhaus, T. Gerz, H. Ziereis, M. Krautstrunk, C. Mallaun, J.-F. Gayet, K. Lieke, K. Kandler, M. Ebert, S. Weinbruch, A. Stohl, J. Gasteiger, H. Olafsson and K. Sturm, Airborne observations of the Eyjafjalla volcano ash cloud over Europe during air space closure in April and May 2010. Atmospheric Chemistry and Physics Discussions, 10 (2010), pp. 22131-22218

Simpson et al., 2007 W. Simpson, R. von Glasow, K. Riedel, P. Anderson, P. Ariya, J. Bottenheim, J. Burrows, L. Carpenter, U. Friess, M. Goodsite, D. Heard, M. Hutterli, H.-W. Jacobi, L. Kaleschke, B. Neff, J. Plane, U. Platt, A. Richter, H. Roscoe, R. Sander, P. Shepson, J. Sodeau, A. Steffen, T. Wagner and E. Wolff, Halogens and their role in polar boundary-layer ozone depletion. Atmospheric Chemistry and Physics, 7 (2007), pp. 43754418.

Slusher et al., 2010 D. Slusher, W. Neff, S. Kim, L. Huey, Y. Wang, T. Zeng, D. Tanner, D. Blake, A. Beyersdorf, B. Lefer, J. Crawford, F. Eisele, R. Mauldin, E. Kosciuch, M. Buhr, H. Wallace and D. Davis, Atmospheric chemistry results from the ANTCI 2005 Antarctic plateau airborne study. Journal of Geophysical Research, 115 D07304 (2010).

Stutz et al., 2000 J. Stutz, E.S. Kim, U. Platt, P. Bruno, C. Perrino and A. Febo, UV-visible absorption cross sections of nitrous acid. Journal of Geophysical Research, 105 (2000), pp. 14585-14592.

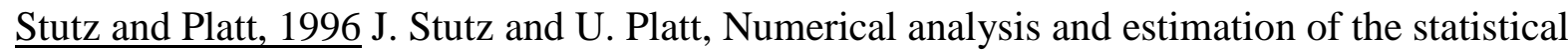
error of differential optical absorption spectroscopy measurements with least-squares methods. Applied Optics, 3530 (1996), pp. 6041-6053

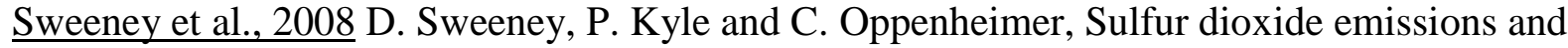
degassing behavior of Erebus volcano, Antarctica. Journal of Volcanology and Geothermal Research, 177 (2008), pp. 725-733.

Vallelonga et al., 2002 P. Vallelonga, K. Van de Velde, J.-P. Candelone, V. Morgan, C. Boutron and K. Rosman, The lead pollution history of Law Dome, Antarctica, from isotopic measurements 736 on ice cores: 1500 AD to 1989 AD. Earth and Planetary Science Letters, 204 (2002), pp. 291-306.

Voigt et al., 2001 S. Voigt, J. Orphal, K. Bogumil and J. Burrows, The temperature dependence (203-293 K) of the absorption cross-sections of $\mathrm{O}_{3}$ in the $230-850 \mathrm{~nm}$ region measured by Fourier-Transform spectroscopy. Journal of Photochemistry and Photobiology A: Chemistry, 143 (2001), pp. 1-9. 
Voigt et al., 2002 S. Voigt, J. Orphal and J. Burrows, The temperature and pressure dependence of the absorption cross-sections of $\mathrm{NO}_{2}$ in the $250-800 \mathrm{~nm}$ region measured by Fourier-transform spectroscopy. Journal of Photochemistry and Photobiology A:

Chemistry, 149 (2002), pp. 1-7.

von Glasow, 2010 R. von Glasow, Atmospheric chemistry in volcanic plumes. Proceedings of the National Academy of Sciences, 107 (2010), pp. 6594-6599.

von Glasow et al., 2009 R. von Glasow, N. Bobrowski and C. Kern, The effects of volcanic eruptions on atmospheric chemistry. Chemical Geology, 263 (2009), pp. 131-142.

von Glasow and Crutzen, 2003 R. von Glasow and P. Crutzen, Tropospheric halogen chemistry, Treatise on Geochemistry - The Atmosphere, vol. 4 , in: R. Keeling, H. Holland, K. Turekion, Editors Elsevier/Pergamon, Oxford (2003), pp. 21-64.

Vountas et al., 1998 M. Vountas, V. Rozanov and J. Burrows, Ring effect: impact of rotational Raman scattering on radiative transfer in Earth's atmosphere. Journal of Quantitative Spectroscopy and Radiative Transfer, 606 (1998), pp. 943-961.

Wardell et al., 2008 L.J. Wardell, P. Kyle and D. Counce, Volcanic emissions of metals and halogens from White Island (New Zealand) and Erebus volcano (Antarctica) determined with chemical traps. Journal of Volcanology and Geothermal Research, 177 (2008), pp. 734-742.

Wardell et al., 2004 L.J. Wardell, P.R. Kyle and C. Chaffin, Carbon dioxide and carbon monoxide emission rates from an alkaline intra-plate volcano: Mount Erebus, Antarctica. Journal of Volcanology and Geothermal Research, 131 (2004), pp. 109-121.

Zoller et al., 1974 W.H. Zoller, E. Gladney and R. Duce, Atmospheric concentrations and sources of trace elements at the South Pole. Science, 183 (1974), pp. 198-200

Zreda-Gostynska, 1995 Zreda-Gostynska, G., 1995. Characterization of gas and aerosol emissions from Mount Erebus Volcano, Antarctica. Ph.D. Thesis, New Mexico Institute of Mining and Technology..

Zreda-Gostynska et al., 1993 G. Zreda-Gostynska, P. Kyle, D. Finnegan and K. Prestbo, Chlorine, fluorine, and sulfur emissions from Mount Erebus, Antarctica and estimated contributions to the Antarctic atmosphere. Geophysical Research Letters, 20 (1993), pp. 1959-1962.

Zreda-Gostynska et al., 1997 G. Zreda-Gostynska, P. Kyle, D. Finnegan and K. Prestbo, Volcanic gas emissions from Mount Erebus and their impact on the Antarctic environment. Journal of Geophysical Research, 102 B7 (1997), pp. 15039-15056. 


\section{Figures and Tables}

Table 1. Table of reported worldwide volcanogenic $\mathrm{BrO}$ observations (sorted according to decreasing $\mathrm{BrO} / \mathrm{SO}_{2}$ molar ratio).

\begin{tabular}{|c|c|c|c|c|c|c|}
\hline Date & Volcano & $\begin{array}{l}\mathrm{BrO} / \mathrm{SO}_{2} \\
(\mathrm{molec}) \times 10^{-4}\end{array}$ & $\begin{array}{l}\operatorname{Max}(\text { or avg }) \text { BrO CA } \\
\left(\times 10^{14} \mathrm{molec} / \mathrm{cm}^{2}\right)\end{array}$ & $\begin{array}{l}\mathrm{SO}_{2} \text { flux } \\
(\mathrm{kg} / \mathrm{s})\end{array}$ & $\begin{array}{l}\text { Distance from source } \\
\text { where plume is crossed } \\
(\mathbf{k m})\end{array}$ & Reference \\
\hline $\begin{array}{l}\text { May } \\
02\end{array}$ & $\begin{array}{l}\text { Soufrière } \\
\text { Hills }\end{array}$ & 10 & 8.4 & & 4 & Bob03 \\
\hline $\begin{array}{l}\text { May } \\
04\end{array}$ & Sakurajima & 10 & 10 & - & A few $\mathrm{km}$ & Lee05 \\
\hline $\begin{array}{l}\text { Aug } \\
07\end{array}$ & Ambrym & $4.5-7.0$ & $6.6-8.3 \times 10^{3}$ (avg) & $39-59$ & $13-14$ & Ban09 \\
\hline $\begin{array}{l}\text { Jan } \\
07\end{array}$ & & $2.3-4.1$ & $1.7 \times 10^{4}$ (avg) & 179-268 & $15-40$ & Ban09 \\
\hline $\begin{array}{l}\text { Mar } \\
07\end{array}$ & & 0.1 & $1.0 \times 10^{4}(\mathrm{avg})$ & 382 & 11 & Ban09 \\
\hline Jul 07 & & 0.5 & $7.5 \times 10^{3}(\mathrm{avg})$ & 25 & 4 & Ban09 \\
\hline $\begin{array}{l}\text { Sep } \\
03\end{array}$ & Etna & 4.8 & 1.1 & - & 7 & Bob07 \\
\hline $\begin{array}{l}\text { Aug } \\
04 /\end{array}$ & & $0-4.5$ & 5 & - & 0-19 & Bob07 \\
\hline \multicolumn{7}{|l|}{$\begin{array}{l}\text { May } \\
05\end{array}$} \\
\hline $\begin{array}{l}\text { Aug } \\
04\end{array}$ & & 2.1 & 4.8 & - & 2.5 & Bob07 \\
\hline $\begin{array}{l}\text { Aug } \\
04\end{array}$ & & 1.9 & 3 & 11 & $2-3$ & 0pp06 \\
\hline $\begin{array}{l}\text { Dec } \\
05\end{array}$ & Erebus & 2.5 & 5.1 & $0.7 \pm 0.3$ & $\sim 0.4$ & Boi11a \\
\hline $\begin{array}{l}\text { Sep } \\
04\end{array}$ & Stromboli & 2.1 & 6.9 & - & 2 & Bob07 \\
\hline $\begin{array}{l}\text { Nov } \\
04\end{array}$ & Villarica & 1.3 & 1,3 & - & 4 & Bob07 \\
\hline $\begin{array}{l}\text { Mar } \\
03\end{array}$ & Masaya & 0.8 & 1.9 & - & 0.6 & Bob07 \\
\hline $\begin{array}{l}\text { Apr } \\
07\end{array}$ & & 0.3 & 2.7 & & Above crater & Ker09 \\
\hline $\begin{array}{l}\text { Nov } \\
08\end{array}$ & Popocatépetl & 0.3 & 3 & $16-31$ & $\sim 0.4$ & Boi11b \\
\hline
\end{tabular}

Ban09: Bani et al. (2009), Bob03; Bobrowski et al. (2003), Bob07: Bobrowski and Platt (2007), Boi11a: [This study], Boil1b: (Boichu in preparation), Ker09; Kern et al. (2009), Lee05: Lee et al. (2005), 0pp06: Oppenheimer et al (2006). 
Table 2. Details of the DOAS experiment performed on 3 December 2005 in which BrO was detected.

\begin{tabular}{|l|l|l|l|}
\hline Date, dataset & $\begin{array}{l}\text { Integration time (ms), co-added } \\
\text { spectra }\end{array}$ & $\begin{array}{l}\text { Elevation, azimuth } \\
\left({ }^{\circ}\right)\end{array}$ & Local time \\
\hline 3 Dec 05, static1 & 100,50 & 15,160 & $\begin{array}{l}09: 29- \\
11: 47\end{array}$ \\
\hline 3 Dec 05, static2 & 100,50 & 15,160 & $\begin{array}{l}11: 49- \\
12: 34\end{array}$ \\
\hline 3 Dec 05, static3 & 100,50 & 15,160 & $\begin{array}{l}12: 35- \\
13: 35\end{array}$ \\
\hline $\begin{array}{l}\text { 3 Dec 05, } \\
\text { static3b }\end{array}$ & 100,100 & 15,160 & $\begin{array}{l}13: 59- \\
15: 33\end{array}$ \\
\hline
\end{tabular}


Table 3. BrO detection limits for DOAS experiments performed in December 2005 in which $\mathrm{BrO}$ could not be detected. For comparison, details of the 3 December 2005 dataset from which $\mathrm{BrO}$ was identified are provided at the bottom of the table. All data were analyzed following the same retrieval method as described in Section 2 .

\begin{tabular}{|c|c|c|c|c|c|c|c|c|c|c|}
\hline $\begin{array}{l}\text { Date, } \\
\text { datas } \\
\text { et }\end{array}$ & $\begin{array}{l}\text { Integrat } \\
\text { ion time } \\
(\mathbf{m s}), \text { co- } \\
\text { added } \\
\text { spectra }\end{array}$ & $\begin{array}{l}\text { Loca } \\
\text { l } \\
\text { time }\end{array}$ & $\begin{array}{l}\text { Elevati } \\
\text { on, } \\
\text { azimut } \\
\text { h }\left(^{\circ}\right)\end{array}$ & $\begin{array}{l}\text { USB20 } \\
\text { 00 ID }\end{array}$ & $\begin{array}{l}\text { Fit } \\
\text { windo } \\
\text { w, nm }\end{array}$ & \begin{tabular}{|l|}
$\Delta \sigma_{\mathrm{BrO}}^{\prime} \mathrm{a}_{\text {in }}$ \\
$10^{-17} \mathbf{c m}^{2} \mathbf{m o}$ \\
$\operatorname{lec}^{-1}$
\end{tabular} & $\begin{array}{l}\text { Fit } \\
\text { resid } \\
\text { ual } \\
\text { std in } \\
10^{-3}\end{array}$ & $\begin{array}{l}\text { BrO } \\
\text { detection } \\
\text { limit }^{\mathbf{b}} \text { in } \\
10^{14} \text { molec } \\
\mathrm{cm}^{-2}\end{array}$ & $\begin{array}{l}{\mathrm{Max} \mathrm{SO}_{2}} \mathrm{CA} \text { in } \\
10^{17} \text { molec } \\
\mathrm{cm}^{-2}\end{array}$ & $\begin{array}{l}\text { Expected } \\
\text { max BrO } \\
\mathrm{CA}^{\mathrm{c}} \text { in } \\
10^{14} \text { molec } \\
\mathrm{cm}^{-2}\end{array}$ \\
\hline $\begin{array}{l}4 \\
\text { Dec, } \\
\text { static } \\
1\end{array}$ & 200,25 & $\begin{array}{l}17: 2 \\
3- \\
17: 3 \\
9\end{array}$ & 15,160 & 11108 & $\begin{array}{l}310.9 \\
377.8\end{array}$ & 1.4 & 1.5 & 2.1 & 2.2 & 0.5 \\
\hline $\begin{array}{l}4 \\
\text { Dec, } \\
\text { static } \\
2\end{array}$ & 125,50 & \begin{tabular}{|l|}
$17: 4$ \\
$6-$ \\
$18: 2$ \\
1
\end{tabular} & 12,250 & 11108 & $\begin{array}{l}310.9 \\
377.8\end{array}$ & 1.4 & 0.8 & 1.1 & 1.2 & 0.3 \\
\hline $\begin{array}{l}4 \\
\text { Dec, } \\
\text { static } \\
3\end{array}$ & 150,40 & \begin{tabular}{|l|}
$18: 3$ \\
$2-$ \\
$18: 5$ \\
8
\end{tabular} & 15,210 & 11108 & $\begin{array}{l}310.9 \\
377.8\end{array}$ & 1.4 & 0.9 & 1.3 & 1.5 & 0.4 \\
\hline $\begin{array}{l}4 \\
\text { Dec, } \\
\text { static } \\
4\end{array}$ & 250,20 & $\begin{array}{l}18: 3 \\
2- \\
18: 5 \\
8\end{array}$ & 15,160 & 11108 & $\begin{array}{l}310.9 \\
377.8\end{array}$ & 1.4 & 2.9 & 4.1 & 4.9 & 1.2 \\
\hline $\begin{array}{l}5 \\
\text { Dec, } \\
\text { static } \\
1\end{array}$ & 125,40 & $\begin{array}{l}14: 4 \\
2- \\
20: 2 \\
4\end{array}$ & 15,160 & 11108 & $\begin{array}{l}310.9 \\
377.8\end{array}$ & 1.4 & 3.4 & 4.8 & 4.4 & 1.1 \\
\hline $\begin{array}{l}9 \\
\text { Dec, } \\
\text { static } \\
1\end{array}$ & 80,100 & \begin{tabular}{|l|}
$07: 3$ \\
$2-$ \\
$08: 5$ \\
5
\end{tabular} & 15,195 & 11107 & $\begin{array}{l}310.9- \\
377.8\end{array}$ & 1.55 & 2.6 & 3.3 & 2.5 & 0.6 \\
\hline $\begin{array}{l}9 \\
\text { Dec, } \\
\text { static } \\
2\end{array}$ & 75,100 & \begin{tabular}{|l|}
$14: 1$ \\
$0-$ \\
$18: 0$ \\
9
\end{tabular} & 15,195 & 11107 & $\begin{array}{l}310.9- \\
377.8\end{array}$ & 1.55 & 2.3 & 3.0 & 2.2 & 0.5 \\
\hline $\begin{array}{l}21 \\
\text { Dec, } \\
\text { scan3 }\end{array}$ & 50,100 & \begin{tabular}{|l|}
$10: 2$ \\
$2-$ \\
$10: 3$ \\
9
\end{tabular} & variable & 11107 & \begin{tabular}{|l|}
$320.6-$ \\
377.6
\end{tabular} & 1.4 & 3.9 & 5.6 & 7.0 & 1.7 \\
\hline $\begin{array}{l}21 \\
\text { Dec, } \\
\text { scan4 }\end{array}$ & 90,50 & \begin{tabular}{|l|}
$10: 4$ \\
$5-$ \\
$12: 0$ \\
6 \\
\end{tabular} & 15,160 & 11107 & \begin{tabular}{|l|}
$315.3-$ \\
367.7
\end{tabular} & 1.55 & 1.4 & 1.8 & 4.2 & 1.0 \\
\hline $\begin{array}{l}21 \\
\text { Dec, } \\
\text { scan5 }\end{array}$ & 60,100 & \begin{tabular}{|l|}
$12: 0$ \\
$8-$ \\
$18: 4$ \\
8 \\
\end{tabular} & 15,160 & 11107 & $\begin{array}{l}310.9- \\
377.8\end{array}$ & 1.55 & 2.7 & 3.5 & 6.1 & 1.5 \\
\hline $\begin{array}{l}3 \\
\text { Dec, } \\
\text { static } \\
3 b\end{array}$ & 100,100 & $\begin{array}{l}13: 5 \\
9- \\
15: 3 \\
3\end{array}$ & 15,160 & 11108 & \begin{tabular}{|l|}
$310.9-$ \\
377.8
\end{tabular} & 1.4 & 1.0 & 1.4 & 10.2 & 2.5 \\
\hline
\end{tabular}


a $\Delta \sigma_{B r O}^{\prime}$ represents the peak-to-peak amplitude of the differential $\mathrm{BrO}$ cross-section at the strongest peak of absorption $(338.5 \mathrm{~nm})$.

${ }^{\mathrm{b}}$ The $\mathrm{BrO}$ detection limit is defined as the ratio of twice the standard deviation of the fit residual to $\Delta \sigma_{B r O}^{\prime}$.

${ }^{\mathrm{c}}$ Assuming a $\mathrm{BrO} / \mathrm{SO}_{2}$ molecular ratio of $2.5 \times 10^{-4}$, as measured on $3 \mathrm{Dec} 05$ in this study (see Section 3.1), we estimate the maximum $\mathrm{BrO}$ column which is expected from the maximum $\mathrm{SO}_{2} \mathrm{CA}$ recorded. 

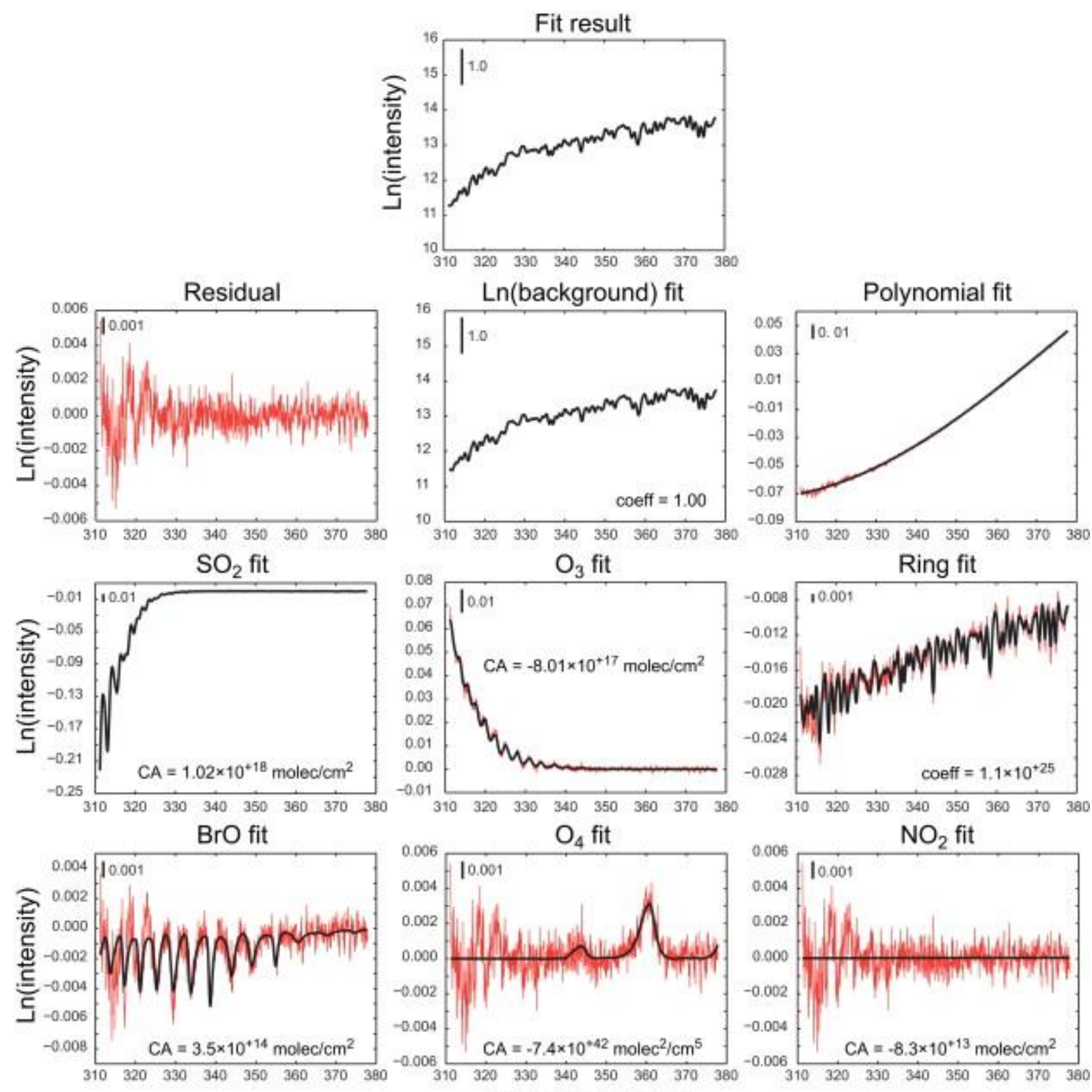

Wavelength $(\mathrm{nm})$

Fig. 1. : Example of BrO fitting process for a spectrum with high volcanic gas content ('static3b data set', 15:01 LT). Thick black lines represent the results of the DOAS fit (note the different scaling of the vertical axis according to the species). Note the failure to detect $\mathrm{NO}_{2}$. Negative column amounts of $\mathrm{O}_{3}$ and $\mathrm{O}_{4}$ suggest a shorter atmospheric light path when the plume is in the DOAS field of view (refer to Section 4.3 for more details). 

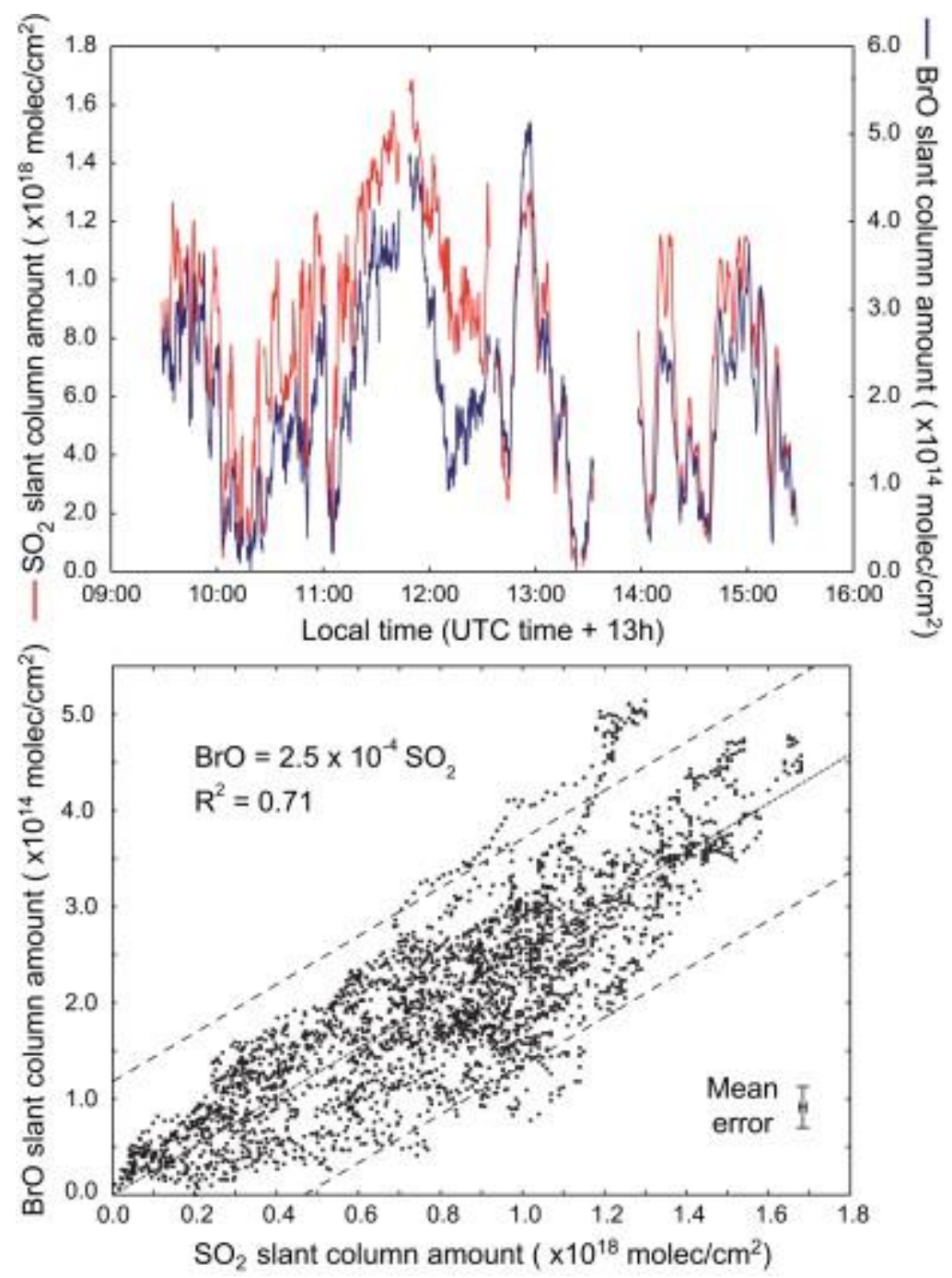

Fig. 2. : (Upper panel) Time-series of $\mathrm{SO}_{2}$ (red) and $\mathrm{BrO}$ (blue) column amounts (molec $\mathrm{cm}^{-2}$ ) retrieved from spectra collected on 3 December 2005 between 9:29 and 15:30 LT. Note the different scales for each species. (Lower panel) Scatter plot for BrO vs. $\mathrm{SO}_{2}$ column amounts. Mean error bars on column amounts are obtained from the DOAS retrieval. Dotted and dashed lines show, respectively, 95\% confidence and prediction limit of the linear fit. (For interpretation of the references to color in this figure legend, the reader is referred to the web version of this article.). 

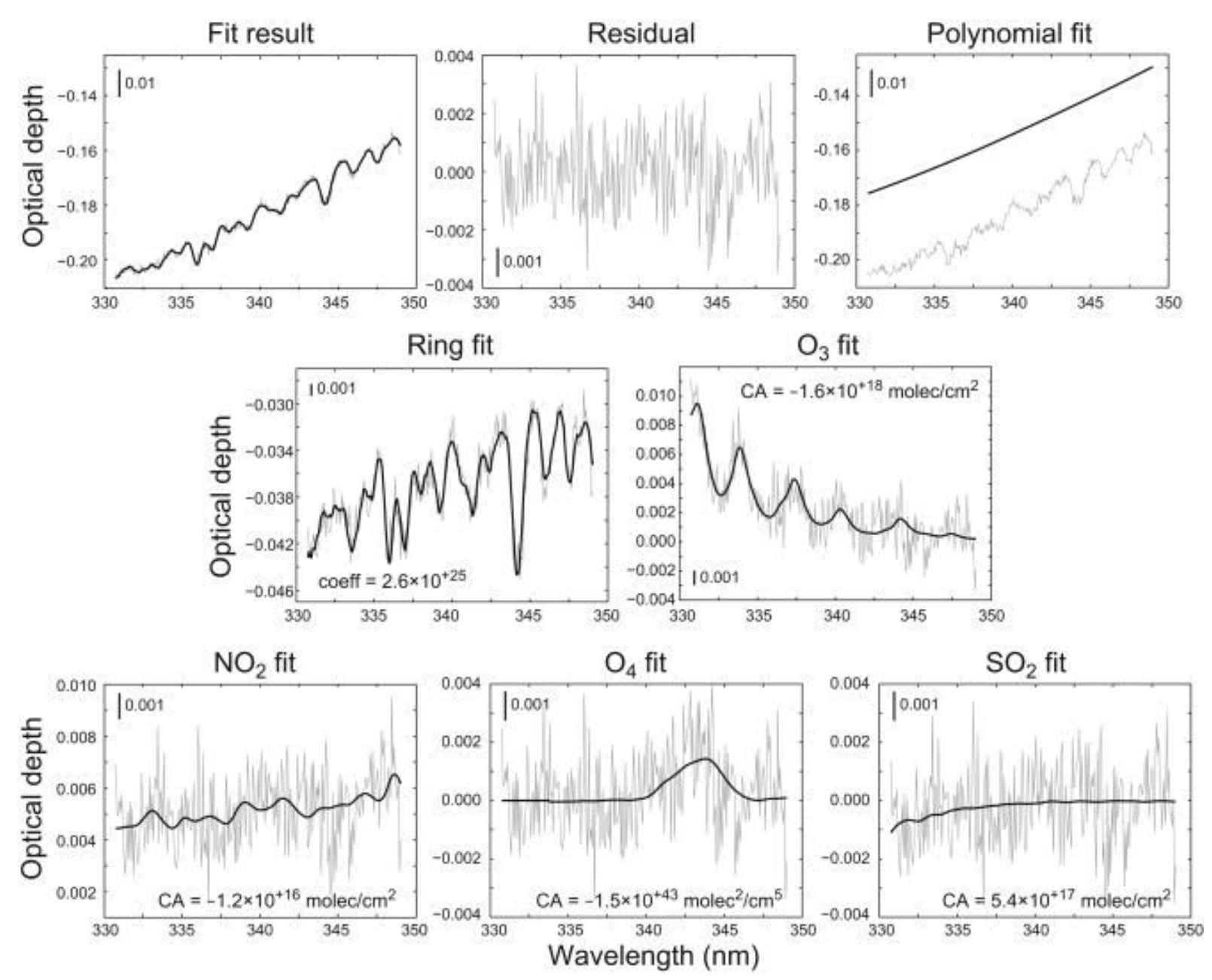

Fig. 3. : Re-evaluation of $\mathrm{NO}_{2}$ in spectra collected on 11 December 2003 and reported by Oppenheimer et al. (2005). Example of $\mathrm{NO}_{2}$ fitting process for spectrum with high volcanic gas content (Set B, 23:09:18 LT). Thick black lines represent the results of the DOAS fit including a third degree polynomial, a Ring spectrum calculated from the background spectrum using DOASIS, and convolved cross-sections of $\mathrm{NO}_{2}$ (Voigt et al., 2002), $\mathrm{SO}_{2}$ (Bogumil et al., 2003), $\mathrm{O}_{3}$ (Voigt et al., 2001) and $\mathrm{O}_{4}$ (Hermans, 2002). To enable direct comparison, the chosen fit window $(330.7-349.0 \mathrm{~nm})$ is identical to the one used by Oppenheimer et al. (2005). Note that the $\mathrm{SO}_{2} \mathrm{SCA}$ is fixed in that fit to $5.4 \times 10^{17} \mathrm{molec} \mathrm{cm}{ }^{-2}$ after retrieval in the range of strongest $\mathrm{SO}_{2}$ absorption in $309.2-334.5 \mathrm{~nm}$. The $\mathrm{BrO}$ crosssection was not included in the final fit since it was not detectable. 


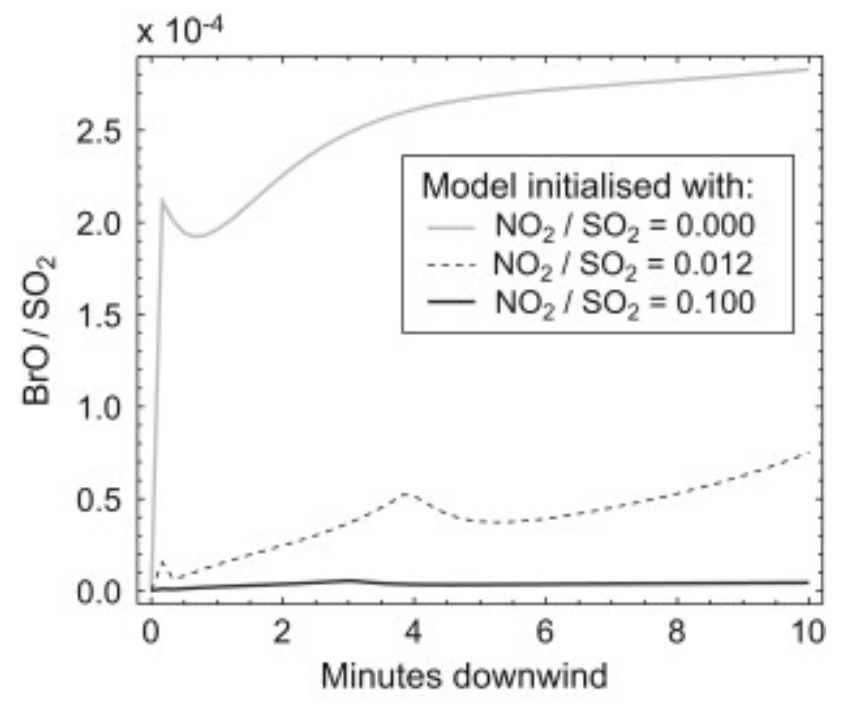

Fig. 4. : Model simulation, based on Roberts et al. (2009), of $\mathrm{BrO} / \mathrm{SO}_{2}$ as a function of plume age, parameterized for three potential volcanic $\mathrm{NO}_{x}$ emission ratios: $\mathrm{NO}_{2} / \mathrm{SO}_{2}=0.10$ (corresponding approximately to the ratio reported by Oppenheimer et al. (2005), $\mathrm{NO}_{2} / \mathrm{SO}_{2}=0.012$ (upper limit of [This study]) and $\mathrm{NO}_{2} / \mathrm{SO}_{2}=0.00$ (lower limit). Simulations were performed for constant $\mathrm{SO}_{2}$ flux of $0.7 \mathrm{~kg} \mathrm{~s}^{-1}$, wind speed of $2 \mathrm{~m} \mathrm{~s}^{-1}$, and a total (aerosol + gas-phase) emitted $\mathrm{Br} / \mathrm{SO}_{2}$ of 0.0015 . As Erebus is a weak emitter, resulting in a dilute plume, the initial plume dilution was set so that $\mathrm{SO}_{2}=2 \mathrm{ppmv}$, with further dispersion over the 10 min simulation resulting in $\mathrm{SO}_{2}=1.3$ ppmv. 


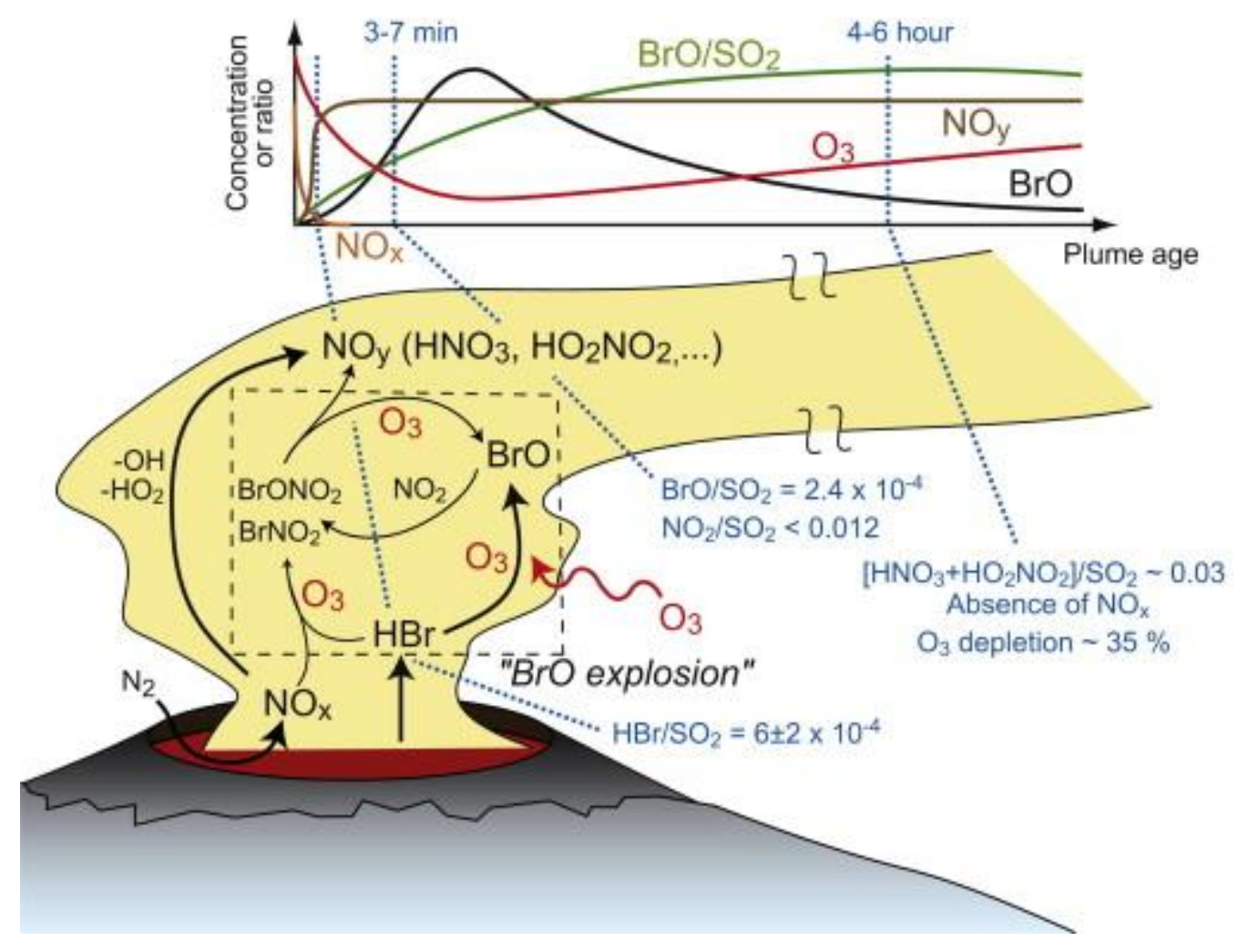

Fig. 5. : Diagram of reactive bromine and nitrogen chemistry in the tropospheric plume emitted by Erebus. (Lower panel) Simplified illustration of the autocatalytic formation of $\mathrm{BrO}$ (also known as the 'BrO explosion') from $\mathrm{HBr}$, which consumes $\mathrm{O}_{3}$. The list of reactions is not exhaustive but the interaction between reactive $\mathrm{NO}_{x}$ and $\mathrm{Br}$ species, which can store $\mathrm{Br}$ molecules in the form of $\mathrm{BrONO}_{2}$ or $\mathrm{BrNO}_{2}$ species and postpone the $\mathrm{BrO}$ explosion, as discussed in Section 4.2, is highlighted. The conversion of $\mathrm{NO}_{x}$ to $\mathrm{NO}_{y}$, involving either reactive $\mathrm{Br}$-chemistry or reactions with $\mathrm{OH}$ and $\mathrm{HO}_{2}$ radicals (see Section 4.2 for more details), is also illustrated. (Upper panel) Qualitative picture of the evolution of $\mathrm{BrO}, \mathrm{O}_{3}$, and $\mathrm{BrO} / \mathrm{SO}_{2}$ as a function of plume age, deduced from models of reactive chemistry and dispersion of a volcanic plume but neglecting $\mathrm{SO}_{2}$ depletion (Roberts et al., 2009). The rapid conversion of $\mathrm{NO}_{x}$ to $\mathrm{NO}_{y}$, discussed in Section 4.2, is also shown. Text in blue summarizes observations (mol) available for the Erebus plume. (For interpretation of the references to colour in this figure legend, the reader is referred to the web version of this article.). 
Table 4. Summary of observations pertaining to gas and aerosol phases involved in reactive halogen and nitrogen chemistry, and ozone depletion in the tropospheric plume of Erebus volcano.

\begin{tabular}{|c|c|c|c|c|c|}
\hline Species & $\begin{array}{l}\text { Crater } \\
\text { rim, } \\
\sim 200 \mathrm{~m} \\
\text { above lake }\end{array}$ & $\begin{array}{l}\text { Above crater, } \\
\sim 400 \mathrm{~m} \text { above } \\
\text { lake }\end{array}$ & $\begin{array}{l}\text { Distant plume } \\
\text { (distance } \\
\text { from crater) }\end{array}$ & Date & Method \\
\hline $\mathrm{SO}_{2}$ flux & - & $\begin{array}{l}0.7 \pm 0.3 \mathrm{~kg} \mathrm{~s}^{-1} \\
(\mathrm{avg})\end{array}$ & - & $\begin{array}{l}\text { Dec 92- } \\
06\end{array}$ & $\operatorname{COSPEC}^{\underline{\mathrm{b}}, \underline{\mathrm{c}}}, \mathrm{DOAS}^{\mathrm{c}, \underline{\mathrm{d}}}$ \\
\hline $\mathrm{HBr} / \mathrm{SO}_{2}$ & $\begin{array}{l}{[4-} \\
8] \times 10^{-4} \\
(\mathrm{~mol})^{\mathrm{a}}\end{array}$ & - & - & $\begin{array}{l}\text { Dec 88- } \\
89-91\end{array}$ & Filter packs ${ }^{\mathrm{e}}$ \\
\hline $\mathrm{Br}^{-} / \mathrm{SO}_{4}{ }^{2-}$ & $\begin{array}{l}0.022- \\
0.028 \\
(\mathrm{~mol})\end{array}$ & - & - & $\begin{array}{l}\text { Dec 06- } \\
07\end{array}$ & Cascade impactor $^{\mathrm{f}}$ \\
\hline $\begin{array}{l}\mathrm{Br} / \mathrm{S} \\
\text { (particles) }\end{array}$ & $\begin{array}{l}0.019- \\
0.032 \\
\text { (mass) }\end{array}$ & - & - & $\begin{array}{l}\text { Dec 88- } \\
89-91\end{array}$ & Filter packs ${ }^{\mathrm{e}}$ \\
\hline $\mathrm{BrO} / \mathrm{SO}_{2}$ & - & $2.5 \times 10^{-4}(\mathrm{~mol})$ & - & 3 Dec 05 & DOAS $^{\mathrm{g}}$ \\
\hline $\mathrm{NO}_{2} / \mathrm{SO}_{2}$ & - & $\leq 0.012(\mathrm{~mol})$ & - & 3 Dec 05 & DOAS $^{\mathrm{g}}$ \\
\hline $\mathrm{NO} / \mathrm{SO}_{2}$ & - & - & Not found & $\begin{array}{l}9-10 \mathrm{Dec} \\
05\end{array}$ & Chemiluminescence $^{\underline{h}}$ \\
\hline $\mathrm{HCl} / \mathrm{SO}_{2}$ & - & $0.28-0.92$ (mass) & - & $\begin{array}{l}\text { Dec 86- } \\
88-89- \\
91 / 97- \\
99-00 / 04\end{array}$ & $\begin{array}{l}\mathrm{FP}^{\mathrm{i}} / \mathrm{Chemical}^{\mathrm{i}} / \mathrm{TTIR}^{\mathrm{k}} \\
\text { traps }^{\mathrm{k}} \text {. }\end{array}$ \\
\hline \multirow[t]{2}{*}{$\mathrm{HNO}_{3} / \mathrm{SO}_{2}$} & - & - & $\begin{array}{l}{[17.8-} \\
18.5] \times 10^{-3} \\
(\mathrm{~mol})\end{array}$ & $\begin{array}{l}9-10 \text { Dec } \\
05\end{array}$ & Mass spectrometry ${ }^{\underline{h}}$ \\
\hline & & & $(1-56 \mathrm{~km})$ & & \\
\hline \multirow[t]{2}{*}{$\mathrm{HO}_{2} \mathrm{NO}_{2} / \mathrm{SO}_{2}$} & - & - & $\begin{array}{l}{[10.5-} \\
10.9] \times 10^{-3} \\
(\mathrm{~mol})\end{array}$ & $\begin{array}{l}9-10 \mathrm{Dec} \\
05\end{array}$ & Mass spectrometry ${ }^{\mathrm{h}}$ \\
\hline & & & $(1-56 \mathrm{~km})$ & & \\
\hline \multirow[t]{2}{*}{$\mathrm{O}_{3}$} & - & - & $\begin{array}{l}\text { Depletion up } \\
\text { to } 35 \%\end{array}$ & $\begin{array}{l}10 \mathrm{Dec} \\
05\end{array}$ & $\begin{array}{l}\text { In-situ UV } \\
\text { absorption }\end{array}$ \\
\hline & & & $\begin{array}{l}(\mathrm{mol})(26- \\
39 \mathrm{~km})\end{array}$ & & \\
\hline
\end{tabular}

${ }^{a}$ Calculated from a $\mathrm{Br} / \mathrm{S}$ mass ratio in the acid gas phase trapped by filter packs ranging in 0.0010-0.0021 over the years 1988, 1989 and 1991, and assuming the absence of $\mathrm{H}_{2} \mathrm{~S}$ in the plume (Oppenheimer and Kyle, 2008). This value is likely an under-estimation given the use of LiOH treated filters by Zreda-Gostynska (1995), which are more than two times less efficient in trapping $\mathrm{Br}$ than other treated filters (Mikelich, 2006).

b (Kyle et al., 1994).

${ }^{c}$ (Sweeney et al., 2008). 
d (Boichu et al., 2010).

${ }^{\mathrm{e}}$ Calculated from Zreda-Gostynska (1995).

f (Ilyinskaya et al., 2010).

$\mathrm{g}$ [This study].

h (Oppenheimer et al., 2010).

i (Zreda-Gostynska et al., 1997).

j (Wardell et al., 2008).

$\mathrm{k}$ (Oppenheimer and Kyle, 2008). 